NBER WORKING PAPER SERIES

\title{
THE DIFFUSION OF MEXICAN IMMIGRANTS DURING THE 1990s: EXPLANATIONS AND IMPACTS
}

\author{
David Card \\ Ethan G. Lewis \\ Working Paper 11552 \\ http://www.nber.org/papers/w11552 \\ NATIONAL BUREAU OF ECONOMIC RESEARCH \\ 1050 Massachusetts Avenue \\ Cambridge, MA 02138 \\ August 2005
}

We are grateful to Elizabeth Cascio and Christian Dustmann for helpful discussion, and to George Borjas, Lawrence Katz, and other seminar participants for comments and suggestions. Card's research was supported by a grant from the National Institute of Child Health and Development. The views expressed herein are those of the author(s) and do not necessarily reflect the views of the National Bureau of Economic Research.

(C2005 by David Card and Ethan G. Lewis. All rights reserved. Short sections of text, not to exceed two paragraphs, may be quoted without explicit permission provided that full credit, including $\odot$ notice, is given to the source. 
The Diffusion of Mexican Immigrants During the 1990s: Explanations and Impacts David Card Ethan G. Lewis

NBER Working Paper No. 11552

August 2005

JEL No. J61

\section{ABSTRACT}

Mexican immigrants were historically clustered in a few cities, mainly in California and Texas. During the past 15 years, however, arrivals from Mexico established sizeable immigrant communities in many "new" cities. We explore the causes and consequences of the widening geographic diffusion of Mexican immigrants. A combination of demand-pull and supply push factors explains most of the inter-city variation in inflows of Mexican immigrants over the 1990s, and also illuminates the most important trend in the destination choices of new Mexican immigrants - the move away from Los Angeles. Mexican inflows raise the relative supply of low-education labor in a city, leading to the question of how cities adapt to these shifts. One mechanism, suggested by the Hecksher Olin model, is shifting industry composition. We find limited evidence of this mechanism: most of the increases in the relative supply of low-education labor are absorbed by changes in skill intensity within narrowly defined industries. Such adjustments could be readily explained if Mexican immigrant inflows had large effects on the relative wage structures of different cities. As has been found in previous studies of the local impacts of immigration, however, our analysis suggests that relative wage adjustments are small.

\section{David Card}

Department of Economics

549 Evans Hall, \#3880

UC Berkeley

Berkeley, CA 94720-3880

and NBER

card@econ.berkeley.edu
Ethan G. Lewis

Federal Reserve Bank of Philadelphia

Research Department

Ten Independence Mall

Philadelphia, PA 19106

ethan.g.lewis@phil.frb.org 
During the 1990's the number of Mexican immigrants living in the United States rose by nearly five million people. This rapid growth is illustrated by the solid line in Figure 1, which shows the number of working-age Mexican immigrants recorded in the 2000 Census by year of arrival in the U.S. ${ }^{1}$ At the time of the Census Mexican immigrants represented more than 4 percent of the working age population, nearly double their proportion in 1990. The surge in arrivals from Mexico was accompanied by a remarkable shift in their residence patterns. In previous decades nearly 80 percent of Mexican immigrants settled in either California or Texas. Over the 1990s, however, this fraction fell rapidly. As shown by the dotted line in Figure 1, less than one-half of the most recent Mexican immigrants were living in California or Texas in 2000. Many cities that had very few Mexican immigrants in 1990 - including Atlanta, Raleigh-Durham, Portland, and Seattle - gained significant Mexican populations. The arrival of Mexican immigrants to Southeastern cities like Atlanta is especially interesting because of their potential impact on the labor market prospects of less-skilled African Americans.

In this paper we explore potential explanations for the widening geographic distribution of Mexican immigrants, and examine the impacts of Mexican immigration on local labor markets across the country. We begin with a descriptive overview of the location choices and other characteristics of recent Mexican immigrants. Post-1990 Mexican immigrants are similar to earlier cohorts in their levels of education and English-speaking ability. They differ mainly in their destinations: those who arrived in the 1990s were less likely to move to Los Angeles (the traditional destination of about one-third of all Mexican immigrants) and more likely to move to cities in the Southeast, Northwest, and Mountain states. There is also a shift in industry of employment, with fewer of the recent arrivals employed in agriculture, and offsetting increases in the fractions employed in construction

\footnotetext{
${ }^{1}$ The jagged nature of the line reflects the tendency of Census respondents to report that they arrived $5,10,15, \ldots$ years ago.
} 
(for men) and retail trade (for women).

We then go on to a more formal analysis of the role of "supply push" and "demand pull" factors in explaining the diffusion of Mexican immigrants across U.S. cities in the 1990s. Supplies of potential immigrants were rising over the decade, driven by population growth, falling real wages, and persistently weak economic conditions in Mexico. ${ }^{2}$ Historically, new immigrants tend to follow earlier immigrants from the same country. Thus, we use information on the fraction of Mexican immigrants in a city in 1980 and 1990 as predictors of the "supply push" component of immigrant flows. On the demand side, we use predicted county-level employment growth over the 1990s, extrapolated from trends in the 1980s, as a measure of exogenous employment demand growth. Both factors are significant predictors of Mexican immigrant inflows, with supply push factors explaining 75 percent of the inter-city variation in inflow rates over the 1990s, and demand pull factors explaining another 10 percent. $^{3}$ By comparison, the relative wages and employment rates of Mexican immigrants in a city in 1990 are uncorrelated with subsequent inflows.

The remainder of the paper is focused on understanding how inflows of Mexican immigrants have affected local labor market conditions. We begin by showing that arrivals of Mexicans lead to increases in the relative supply of less-educated labor in the local economy. There is no evidence that the relationship is biased by the endogeneity of Mexican inflows, or that inflows of recent Mexican immigrants cause outflows of other groups that offset their effects on the skill distribution in the local economy. We then examine the role of changing industry structure in explaining the absorption of relatively unskilled population inflows. The Hecksher-Olin (HO) model of trade suggests that shifts in the relative supply of unskilled labor can be absorbed by

${ }^{2}$ Real wages in Mexico were about 20 percent lower in 2000 than in 1990. See OECD (2000, p. 32). ${ }^{3}$ The two components are almost orthogonal so their contributions "add up". 
expanding employment in low-skill-intensive industries, with little or no change in relative wages of unskilled workers. We develop a simple decomposition that allows us to characterize the fraction of the excess supply of dropout labor in a local market that has been absorbed by HO-style industry shifts. We conclude that between-industry shifts account for only a small fraction of the overall absorption of the extra dropout labor created by Mexican inflows.

In view of this finding, we turn to the impact of Mexican immigration on the relative wage structure. We construct estimates of the wage gap in each city between native men with exactly 12 years of schooling and those who did not complete high school, and relate this gap to the relative supply of dropouts in the local market. Consistent with most of the existing literature (see, e.g., Card, 2004) we find that increases in the relative supply of dropouts induced by Mexican immigration inflows have little effect on relative wages of less-educated natives. The absence of a large effect on relative wages is especially puzzling given that most of the absorption of the excess supply of dropout labor created by Mexican immigrant inflows arises within narrowly defined (3digit) industries. Evidently, the adjustments needed to accommodate differences in the relative supply of dropout labor in different markets occur without the intervening mechanism of relative wage changes. The data do not allow us to tell whether this is because high school dropouts and high school graduates are nearly perfect substitutes, or as a result of other adjustment processes such as endogenous technical change.

I. An Overview of Mexican Immigration in the 1990s

a. Census Data

Our empirical analysis is based on public use data from the 1980, 1990, and 2000 Censuses. The primary advantages of these data files are sample size and geographic coverage. For example, 
the 1980 Census includes 109,628 Mexican immigrants (72\% of whom are between the ages of 16 and 65) and identifies more than 300 separate Metropolitan Statistical Areas (MSA's). The main disadvantage of the Census files is under-coverage of Mexican immigrants. Calculations by Borjas, Freeman, and Lang (1991) suggest that the 1980 Census missed approximately 40 percent of unauthorized Mexican immigrants, leading to a $25 \%$ undercount in the overall Mexican immigrant population. ${ }^{4}$ Van Hook and Bean (1998) use a similar method to estimate a 30\% undercount rate of unauthorized Mexicans in the 1990 Census and a 20\% undercount of all Mexicans. ${ }^{5}$ The 2000 Census was substantially more successful than earlier ones in counting unauthorized immigrants (Norwood et al, 2004), leading to undercount rates for unauthorized immigrants on the order of 10 percent (US Citizenship and Immigration Service, 2003), and implying an undercount of total Mexican immigrants of 6-8\%. ${ }^{6}$ Based on these estimates, we believe that problems caused by the undercount of unauthorized Mexicans are likely to be relatively modest in our 2000 data, but more of an issue in interpreting the 1980 and 1990 data.

With these caveats in mind, we turn to Table 1, which presents information on the characteristics of working age Mexican immigrants in the 1980, 1990 and 2000 Censuses. ${ }^{7}$ The

${ }^{4}$ Estimates of the overall Census undercount rates (based on sets of households that were identified and interviewed in two separate counts) are 1.2\% for the 1980 Census, $1.6 \%$ for 1990 , and 0.1 to $1.1 \%$ for 2000. Estimated undercount rates are higher for Hispanics (e.g. around 5\% in the 1990 Census (Hogan, 1993), and 1-4\% in the 2000 Census (Elliot and Little, 2004)). Estimates of undercount rates for the unauthorized population are based on comparisons of birth and/or death rates to population estimates.

${ }^{5}$ Van Hook and Bean show the sensitivity of their estimates to various assumptions. The 30 percent undercount rate is based on relatively conservative assumptions. Other assumptions lead to lower undercount rates, on average.

${ }^{6}$ Passel (2002) estimates that 80 percent of all Mexican immigrants who arrived in the 1990s were unauthorized.

${ }^{7}$ We define Mexican immigrants as Census respondents who report that they are either naturalized citizens or non-citizens, and who report that their place of birth is Mexico. 
demographic characteristics are fairly stable over time, though the average age of Mexican immigrants and their number of years in the U.S. are rising slowly. There is also a modest upward trend in average education. Even in 2000, however, $70 \%$ report having less than a high school education, and more than one half reports low or very low English ability. ${ }^{8}$ The fraction of Mexican immigrants living in either California or Texas was stable between 1980 and 1990, but as noted in the introduction the fraction living in California dropped by 14 percentage points over the 1990s. Roughly 90 percent of Mexican immigrants lived in a larger urban area (i.e., and MSA or CMSA) in 1980 and this rate has not changed much over the past two decades. Finally, the labor market outcomes of Mexican immigrant suggest relatively constant employment rates, but a more variable pattern for wages, with declines in both real and relative wages over the 1980s, and a modest rebound in real wages over the 1990s. These trends are roughly consistent with wage trends for native dropout workers in the U.S.

\section{b. Inter-cohort Comparisons}

Although comparisons across the Mexican populations in 1980, 1990, and 2000 are informative, they potentially mask differences between newly arriving and earlier cohorts of Mexicans. Figures 2-8 compare Mexican immigrants by years of residence in the U.S. in 1990 and 2000. Figure 2 focuses on the fractions living in California and Texas. In 1990 the probabilities of living in California or Texas were largely independent of the number of years in the U.S. In the 2000 data, however, recent arrivals are much less likely to live in California than earlier cohorts. These simple comparisons suggest that most of the widening geographic diffusion of Mexican

${ }^{8}$ Based on observation at an English instruction class for immigrant parents, we suspect that Mexican immigrants tend to over-report their education. Many immigrants from rural areas attended ungraded schools with interruptions for work at home, so "years of school" may overstate actual years of full time learning. 
immigrants during the 1990 s was attributable to the behavior of new immigrants, rather than to the relocation of older arrival cohorts.

Figures 3 and 4 compare the fractions of Mexican immigrants with less than a high school degree and with low English ability. Female immigrants from Mexico have about the same probability of below-high-school education as males, but have worse language skills. Recent arrivals of either gender in the 2000 Census have a slightly lower probability of below-high school education than their counterparts in 1990, perhaps reflecting gains in education for younger cohorts in Mexico. The levels of low English ability, on the other hand, are very similar in 1990 and 2000.9 Although we do not present them here, the marital status profiles for men and women are also remarkably similar in the two Censuses.

Figure 5 shows mean log hourly wages (in 1999 dollars) by gender and time in the U.S. There was a modest rise in real wages for more recent arrivals over the 1990s, but not much gain for longer-term residents. Overall, however, the wage profiles are quite similar in 1990 and 2000. We have also constructed profiles of employment probabilities (based on the likelihood of reporting positive weeks of work in the past year). For men the 1990 and 2000 profiles are very close together, while for women there is a slightly lower employment rate in 2000 for those who have been in the U.S. for 6-10 years, and not much difference elsewhere. ${ }^{10}$

Finally, Figures 6-8 show the fractions of Mexican workers employed in agriculture, construction, and retail trade. The dominant feature of Figure 6 is the decline in the fraction of

${ }^{9}$ To the extent that the immigrants who are most likely to be undercounted in the Census are recent arrivals with low education and language ability, there may be more reporting bias in the 1990 Census data than the 2000 data. This would tend to mask any actual gains in education or English ability that actually occurred over the 1990s.

${ }^{10} \mathrm{As}$ with education and language, there may be some correlation between wages and the probability of under-reporting, especially for recent Mexican immigrants. Assuming this was a bigger problem in 1990, the observed mean wage trends for recent arrival groups may understate the actual growth that occurred. 
recently-arrived immigrants working in agriculture between 1990 and 2000. In 1990 recent immigrants of both genders were more likely to work in agriculture than long-term residents, whereas in 2000 the profiles are relatively flat. Looking across major industry aggregations, we found that the decline in agricultural employment among recent immigrants was offset by rises in the fraction of employment in construction (for men) and retail trade (for women). In 2000, nearly a quarter of recent male Mexican immigrants was working in construction (see Figure 7), while about one-sixth of recent females were working in retail trade (Figure 8). The rises in Mexican employment in these industries are striking because both sectors also employ relatively large fractions of low-skilled native workers, raising the obvious concern about labor market competition.

\section{c. Distribution Across Cities}

As we noted in the introduction, one of the most important changes for Mexican immigrants between 1990 and 2000 was the move out of California. Further information on this phenomenon is provided in Table 2, which shows the changing fractions of Mexican immigrants in the 15 traditional destination cities that had the largest numbers of Mexicans in $1980 .{ }^{11}$ In 1980 , nearly one-third all working age Mexicans were living in Los Angeles. Another 8 percent were living in Chicago, and roughly 4 percent were living in each of Houston, Orange County, San Diego, and El Paso. Over the 1980s the shares in Los Angeles and Chicago fell slightly, but as of 1990 the top five cities still accounted for nearly one-half of all Mexican immigrants. Between 1990 and 2000, however, the share of Mexican immigrants living in Los Angeles dropped by 10 percentage points, accounting for most of the fall in the total California share noted in Figure 1 and Table 1. Though

\footnotetext{
${ }^{11}$ Throughout this paper, we use as "cities" individual MSA's and the constituent PMSA's in consolidated metropolitan areas. Thus, we treat Los Angeles and Orange County California as separate "cities".
} 
the total share in Texas fell by much less, this stability masks a within-state shift from San Antonio and the smaller border cities (El Paso, McAllen, and Brownsville) to the larger urban centers (Houston and Dallas).

Where did the rapidly growing population of Mexican immigrants settle in the 1990s? To answer this question, we calculated the increase in the number of Mexican immigrants in each MSA between 1990 and 2000, and then tabulated the cities by their shares of the total increase in Mexican immigrants. The results for the top 40 cities, which together account for about 80 percent of the overall growth in the Mexican population, are presented in Table 3.

The first three columns of the table show the total working age population of each city in 1990, the number of Mexican immigrants in 1990, and the Mexican immigrant fraction of the local population. The remaining columns present information on the changes in the city between 1990 and 2000, including total population growth (for 16-65 year olds), the growth rate of the Mexican immigrant population, the increase in the total number of Mexican immigrants living in the city, the fraction of the national increase in the Mexican population "absorbed" in the city, and finally the number of post-1990 immigrants living in the city in 2000.

Although Los Angeles' share of Mexican immigrants was falling over the 1990s, the first row of Table 3 shows that the city still absorbed the largest number of Mexican immigrants. In fact, the Mexican population of Los Angeles grew by 34 percent between 1990 and 2000. Since the total population of Mexican working age immigrants grew by 114 percent over the decade, however, Los Angeles would have had to absorb nearly a million Mexicans to maintain its share. In contrast to Los Angeles, Chicago's Mexican immigrant population grew at about the national average rate, implying a near-doubling of the Mexican immigrant density over the 1990s. Dallas and Houston had even faster growth rates in their Mexican populations, together absorbing nearly 10 percent of 
the national rise. Phoenix and Las Vegas - two very rapidly growing cities - also experienced rapid growth in their Mexican immigrant populations.

More surprising than these figures are the large numbers of Mexican immigrants absorbed in Atlanta, New York, and Denver. All three cities are far from the Mexican border and had very low Mexican population densities in 1990, yet together these cities absorbed over $9 \%$ of the total increase in the Mexican immigrant population. Looking further down the table, Portland Oregon, Salt Lake City, Seattle, Washington, D.C. and three cities in North Carolina ( Raleigh-Durham, Greensboro, and Charlotte) also stand out as cities with historically small Mexican immigrant populations that experienced very rapid inflows over the 1990s. Together these 10 cities account for 412,000 of the rise in the adult Mexican population between 1990 and 2000, or $12 \%$ of the national total.

Comparisons of the entries in columns 6 and 8 of Table 3 suggest that in most cities the growth in the total number of working age Mexican immigrants was about the same size as the number of post-1990 Mexican immigrants living there in 2000. This has two implications. On one hand, it suggests that the arrival of new Mexican immigrants had little displacement effect on previous immigrants in the traditional destination cities. On the other, it also implies that most of the growth in the number of Mexicans in "new" destination cities was attributable to the arrival of recent immigrants. These impressions are confirmed by the patterns in Figure 9, which plots the change in the total number of adult Mexican immigrants living in each city between 1990 and 2000 (as a percent of the city's population in 1990) against the inflow rate of new Mexican immigrants, which we define as the number of post-1990 Mexican immigrants in the city in 2000 divided by the city population in 1990. The points for all but two cities lie on or above the 45-degree line, suggesting that in most cities new Mexican inflows led to equivalent or larger increases in the total 
Mexican population. ${ }^{12}$ Only in Los Angeles and El Paso is there any evidence of displacement of older Mexican immigrants by new arrivals. In the labeled cities above the 45-degree line, net inflows of older immigrants complemented the inflows of post-1990 arrivals, amplifying the impact on local population growth.

\section{Modeling the Diffusion of Recent Mexican Immigrants}

In light of this descriptive evidence, we turn to the task of modeling the flows of recent Mexican immigrants to different cities between 1990 and 2000. Our dependent variable is the inflow rate of new Mexican immigrants, defined as the number of post-1990 working age Mexican immigrants observed in a city in the 2000 Census, divided by the working age population of the city in 1990. Following the traditional taxonomy, we develop a framework for measuring the contribution of "supply push" and "demand pull" to total immigrant inflows. We measure demand pull factors by total employment growth in the MSA between 1990 to 2000, derived from County Business Patterns (CBP) data. ${ }^{13}$ There is a potential endogeneity problem with this variable, since immigrant arrivals may stimulate employment growth. Exploiting the persistence in city-specific employment trends, however, we use employment levels from 1982 to 1990 as instruments for the 1990-2000 employment growth rate. Thus, our demand pull measure is the predicted component of overall employment growth in the city, based on employment trends in the preceding decade.

On the supply side, numerous studies have shown that new immigrants tend to go to cities

\footnotetext{
${ }^{12}$ The same conclusion emerges when we plot the data for the 150 largest cities in the U.S. Over this broader set, only 3 cities have notably smaller growth in the total Mexican population than in new Mexican inflows: Los Angeles, El Paso, and Laredo Texas.

${ }^{13}$ Except in New England, MSA's consist of complete counties, so MSA employment is the sum of employment in the constituent counties. For consistency we use fixed 2000 MSA-county definitions.
} 
where earlier waves of immigrants from the same source country have settled (e.g., Bartel, 1989; Card, 2001). Thus, we use the density of Mexican immigrants in a city in 1980 and 1990 as proxies for the magnitude of supply-push immigration flows from Mexico over the 1990-2000 period.

Estimation results from a series of alternative specifications of the model are presented in Table 4. The models are estimated on a sample of 142 larger MSA's that can be consistently defined on a county basis in the 1980,1990 , and 2000 Censuses. ${ }^{14}$ The first column of the table reports a specification that includes only the lagged Mexican immigrant density variables. These supply push proxies are highly significant, and together explain 78 percent of the variation across cities in the recent Mexican immigrant inflow rate. The second column reports a model that includes only the employment growth variable. This is also a significant determinant of new immigrant inflows, explaining about 10 percent of the intercity-variation. A parallel model estimated by instrumental variables is presented in column 5. Interestingly, the point estimate of the effect of employment growth is slightly larger in the IV model, contrary to what might have been expected under the assumption that the OLS estimate is upward biased by the presence of unobserved factors that contribute to both overall employment growth and Mexican inflows. ${ }^{15}$ Finally, the models in columns 3 and 6 include both the lagged density and employment growth variables. Together the demand pull and supply push variables explain $86 \%$ of the intercity variation in new Mexican immigrant inflows. Again, the point estimates of the models are not much different between the OLS and IV specifications. ${ }^{16}$

\footnotetext{
${ }^{14}$ Copies of the computer programs that process the 1980, 1990, and 2000 Census data and construct the city-level variables are available on request.

${ }^{15}$ The OLS estimate is probably downward biased by measurement error, and it appears that this effect dominates any upward endogeneity bias.

${ }^{16}$ The OLS estimate of the demand coefficient in column 3 is 0.0748 , with a standard error of 0.008 . The corresponding IV estimate in column 6 is 0.0675 , with a standard error of 0.012 .
} 
Given the large fraction of Mexican immigrants who traditionally migrated to Los Angeles, and the sharp decline in this fraction over the 1990s, an interesting challenge for our model is to predict the changing flows to Los Angeles. To address this challenge we re-estimated the model in column 3, adding a dummy for the Los Angeles observation. The estimated Los Angeles dummy is -0.025 , with a standard error of 0.013 , while the point estimates of the other coefficients are virtually the same as those reported in column 3. Thus, the model over-predicts the inflow rate of new Mexican immigrants to Los Angeles (predicted inflow rate $=0.096$; actual $=.071$ ), though the magnitude of the prediction error is just on the margin of the range that would be expected by chance. Moreover, the Los Angeles observation is not a large enough outlier to have any affect the coefficient estimates. The model in column 3 predicts that Los Angeles would have attracted about 558,000 new Mexican immigrants over the 1990s, compared to the actual inflow of 413,000. By comparison, if Los Angeles had maintained its 1990 share of Mexican immigrants, it would have attracted 961,000 new Mexican immigrants (an inflow rate of 0.165). ${ }^{17}$ Thus, the decline in the share of Mexican immigrants moving to Los Angeles in the 1990s is largely explained by a combination of slow employment growth in the city and the pattern of the coefficients on lagged immigrant shares, which indicate a tendency for cities with a longer history of Mexican immigration to have slower growth in new arrivals.

Although the simple supply push and demand pull proxies used in the models in columns 3 and 6 explain much of the variation in new Mexican immigrant inflow rates, other factors may also affect the destination choices of potential migrants. An obvious consideration is the labor market success of earlier cohorts of Mexican immigrants in a particular city. We used 1990 Census data to

${ }^{17}$ Los Angeles had 27.9\% of all working age Mexican immigrants in 1990. According to the 2000 Census there were 3,445,000 working age Mexicans who arrived after 1990 in the U.S. in 2000. 
estimate the average employment rate and mean log wage of Mexican male immigrants in each city in 1989 (adjusted for the characteristics of the immigrant populations in each city). ${ }^{18}$ We then included these as additional explanatory variables in the models in columns 4 and 7 of Table 4 . The results suggest that new immigrants tend to go to cities where Mexicans earned higher wages in 1990, although the estimated effects are imprecise. The estimated employment effects are even less precise, and quite small in magnitude. Overall these variable add little to our basic specification.

The models in Table 4 are estimated using unweighted OLS and IV methods. We have also estimated the same specifications using weighted OLS and IV, with the MSA population in 1990 as a weight. The estimated coefficients from the weighted models are similar to the estimates from the unweighted models, and lead to very similar conclusions about the explanatory power of the supply push and demand pull variables. As in the unweighted models, the weighted IV estimates of the employment growth effect are very close to the weighted OLS estimates, giving no indication of an endogeneity problem.

We conclude that a simple model that includes demand pull and supply push factors provides a relatively good description of the destination choices of new Mexican immigrants over the 1990s. A model with just three parameters explains $86 \%$ of the observed inter-city variation in new Mexican immigrant inflow rates. The model cannot fully explain the sharp downturn in the share of Mexican inflows to Los Angeles in the 1990s, but it predicts about $75 \%$ of the observed decline.

\section{Impacts of Mexican Inflows}

${ }^{18}$ To estimate these adjusted outcomes, we fit models for log hourly wages, and the event of working last year, that included education, age, years in the U.S., an indicator for low English ability, and unrestricted city dummies. We then use the city dummies as measures of relative wages and employment probabilities. 


\section{a. Effects on the Relative Supply of Low-Education Labor}

Having documented the relatively large inflows of Mexican immigrants to many cities in the 1990s, we now turn to analyzing the effects of these inflows. A first question is whether inflows of Mexican immigrants lead to any shift in the skill mix of local populations. Many models of local labor market equilibrium have a constant-returns-to-scale feature which implies that population inflows only affect wages and employment to the extent that they shift the relative supply of different skill groups. ${ }^{19}$

As a starting point, Figure 10 plots the change in the fraction of dropouts in the population of each major MSA between 1990 and 2000 against the inflow rate of new Mexican immigrants to the city. If $70 \%$ of recent Mexican arrivals have less than a high school education, and Mexican inflows are orthogonal to all other characteristics in a city, then one would expect the points in Figure 10 to lie along a line with slope 0.7. For reference we have graphed a line with this slope in the Figure. While there is considerable variation in the scatter of points, there is a strong positive relation between Mexican inflows and the change in the dropout share, with a slope that is a little flatter than the reference line.

Table 5 presents a series of regression models that examine more formally the link between Mexican immigrant inflows and the share of low-education workers in a city. The dependent variable for the models in the first two columns is the fraction of dropouts among adult residents of a city in 2000, while in columns 3-5 the dependent variable is the change in the share of dropouts between 1990 and 2000. Looking first at the simple model in column 1, each percentage point increase in the inflow rate of new Mexican immigrants over the 1990s is estimated to raise the

\footnotetext{
${ }^{19}$ Strictly speaking, such a feature requires perfectly elastic supplies of capital to different cities, and no shortage of land within a city. Arguably both features are true for many MSA's, though not necessarily for high density MSA's like Los Angeles or New York.
} 
fraction of dropouts by 1.29 percentage points. This estimate is too large to represent a causal effect of the Mexican inflow. The "problem" is that inflows tend to be larger in cities that have had more Mexican immigrants in the past, who also contribute to the stock of low-educated residents in the city. This fact is illustrated by the model in column 2, which also includes the Mexican inflow rate over the 1980s. Inflows over both decades contribute to the stock of dropout labor in 2000 , confounding a model like the one in column 1.

Arguably, a better specification relates the change in the dropout share to the inflow rate of new Mexican immigrants. As shown by the models in columns 3 and 4, in such a specification each percentage point increase in the inflow rate of new Mexican immigrants is estimated to raise the fraction of dropouts in a city by 0.5 points. This is slightly lower than would be expected under the hypothesis that $70 \%$ of new Mexican immigrants are dropouts, and that there is no correlation between Mexican inflows and other changes in city demographics. Interestingly, the inflow rate of immigrants in the 1980s has no effect on the change in dropout shares between 1990 and 2000, providing a simple specification check for the first-differenced model.

A concern with the models in columns 3 and 4 is that Mexican immigrants may be attracted to cities where there is an unusually high rate of growth in demand for less educated labor. If that is the case, and if less-educated natives (or less-educated immigrants from other countries) are attracted by the same demand factors, then the measured effect of Mexican inflows on the change in the dropout share may overstate their true impact. Such a bias can be reduced or eliminated by using the supply push variables (i.e., the historical fractions of Mexican immigrants in the city) as instruments for the inflow rate of new Mexican immigrants over the 1990s. We implement this procedure in the model in column 5. At the same time, we instrument employment growth in the city with the lagged employment variables used in Table 4. The resulting coefficient estimates are 
not very different from the OLS estimates, and provide no evidence that endogeneity of Mexican immigrant inflows leads to an overstatement of the effect of these flows on the relative fraction of dropout labor in a city. On balance, we conclude there is robust evidence that inflows of Mexican labor increase the share of dropouts in a city, with each percentage point increase in the inflow rate of recent immigrants leading to a one-half percentage point higher dropout share in 2000 .

\section{b. Industry Structure and the Absorption of Mexican Labor}

Since inflows of Mexican labor increase the pool of less-educated labor in a city, it is interesting to ask how these workers are absorbed by local employers. One possibility, suggested by the Hecksher-Olin (HO) model of international trade, is that the industry structure in a city adapts to the relative supply conditions in the local labor market. Indeed, under certain conditions, changes in industry structure can fully accommodate differences in the relative supply of different skill groups in a given city with no change in the relative wage structure. In this section we use the decomposition method of Lewis (2003) to evaluate the role of HO-style adjustments in absorbing differences in the fraction of low education workers in different cities.

The decomposition starts with an identity that expresses the overall fraction of dropouts employed in a given city, $\mathrm{s}^{\mathrm{d}}(\mathrm{c})$, as a weighted sum of the industry shares in the city, times the dropout intensity in each industry:

$$
\begin{aligned}
\mathrm{s}^{\mathrm{d}}(\mathrm{c}) & =1 / \mathrm{N}(\mathrm{c}) \quad \sum_{\mathrm{i}} \mathrm{N}_{\mathrm{i}}^{\mathrm{d}}(\mathrm{c}) \\
& =\sum_{\mathrm{i}} \mathrm{N}_{\mathrm{i}}(\mathrm{c}) / \mathrm{N}(\mathrm{c}) \quad \mathrm{N}_{\mathrm{i}}^{\mathrm{d}}(\mathrm{c}) / \mathrm{N}_{\mathrm{i}}(\mathrm{c}) \\
& =\sum_{\mathrm{i}} \lambda_{\mathrm{i}}(\mathrm{c}) \mathrm{s}_{\mathrm{i}}^{\mathrm{d}}(\mathrm{c}),
\end{aligned}
$$

where $\mathrm{N}(\mathrm{c})$ is total employment in city $\mathrm{c}, \mathrm{N}_{\mathrm{i}}^{\mathrm{d}}(\mathrm{c})$ is the number of dropouts employed in industry $\mathrm{i}$ in city c, $\mathrm{N}_{\mathrm{i}}(\mathrm{c})$ is total employment in industry $\mathrm{i}$ in city $\mathrm{c}, \lambda_{\mathrm{i}}(\mathrm{c}) \equiv \mathrm{N}_{\mathrm{i}}(\mathrm{c}) / \mathrm{N}(\mathrm{c})$ is the employment share of 
industry $\mathrm{i}$ in city $\mathrm{c}$, and $\mathrm{s}_{\mathrm{i}}^{\mathrm{d}}(\mathrm{c})=\mathrm{N}_{\mathrm{i}}^{\mathrm{d}}(\mathrm{c}) / \mathrm{N}_{\mathrm{i}}(\mathrm{c})$ is the share of dropout workers in industry $\mathrm{i}$ in city c. It follows that the gap between $\mathrm{s}^{\mathrm{d}}(\mathrm{c})$ and the national average fraction of dropouts, $\mathrm{s}^{\mathrm{d}}$, can be written as the sum of a "between industry component" B representing shifts in the relative fractions of different industries in the city, a "within industry component" W, representing shifts in the relative fraction of dropout workers in each industry, and an interaction component I:

(2) $\quad \mathrm{s}^{\mathrm{d}}(\mathrm{c})-\mathrm{s}^{\mathrm{d}}=\mathrm{B}(\mathrm{c})+\mathrm{W}(\mathrm{c})+\mathrm{I}(\mathrm{c})$,

where

$$
\begin{aligned}
& \mathrm{B}(\mathrm{c})=\sum_{\mathrm{i}} \mathrm{s}_{\mathrm{i}}^{\mathrm{d}}\left[\lambda_{\mathrm{i}}(\mathrm{c})-\lambda_{\mathrm{i}}\right] \\
& \mathrm{W}(\mathrm{c})=\sum_{\mathrm{i}} \lambda_{\mathrm{i}}\left[\mathrm{s}_{\mathrm{i}}^{\mathrm{d}}(\mathrm{c})-\mathrm{s}_{\mathrm{i}}^{\mathrm{d}}\right] \\
& \mathrm{I}(\mathrm{c})=\sum_{\mathrm{i}}\left[\lambda_{\mathrm{i}}(\mathrm{c})-\lambda_{\mathrm{i}}\right] \times\left[\mathrm{s}_{\mathrm{i}}^{\mathrm{d}}(\mathrm{c})-\mathrm{s}_{\mathrm{i}}^{\mathrm{d}}\right] .
\end{aligned}
$$

Under the idealized conditions of the Hecksher-Olin model, all of the variation in the share of dropout labor across cities can be absorbed by expansion or contraction of high-dropout-intensity industries (i.e., via the $\mathrm{B}(\mathrm{c})$ term), with no city-level variation in relative wages or the dropout intensity of any particular industry. ${ }^{20}$

We use 2000 Census data on employment classified by 3 digit industry to compute the terms in equation (2) for each of 150 larger MSA's. We then performed a series of cross-city regressions of the form:

$$
\begin{aligned}
& \mathrm{B}(\mathrm{c})=\mathrm{a}_{\mathrm{B}}+\mathrm{b}_{\mathrm{B}}\left[\mathrm{s}^{\mathrm{d}}(\mathrm{c})-\mathrm{s}^{\mathrm{d}}\right]+\mathrm{e}_{\mathrm{B}}(\mathrm{c}) \\
& \mathrm{W}(\mathrm{c})=\mathrm{a}_{\mathrm{w}}+\mathrm{b}_{\mathrm{W}}\left[\mathrm{s}^{\mathrm{d}}(\mathrm{c})-\mathrm{s}^{\mathrm{d}}\right]+\mathrm{e}_{\mathrm{w}}(\mathrm{c}) \\
& \mathrm{I}(\mathrm{c})=\mathrm{a}_{\mathrm{I}}+\mathrm{b}_{\mathrm{I}}\left[\mathrm{s}^{\mathrm{d}}(\mathrm{c})-\mathrm{s}^{\mathrm{d}}\right]+\mathrm{e}_{\mathrm{I}}(\mathrm{c}) .
\end{aligned}
$$

Since equation (2) holds as an identity, the coefficients $b_{B}, b_{W}$, and $b_{I}$ sum to 1 . A strict version of

${ }^{20}$ These conditions include infinitely elastic supplies of capital, perfectly integrated product markets, and the existence of at least one industry that produces a tradeable good or service that has a dropout intensity that exceeds the maximum dropout share in any city. 
the $\mathrm{HO}$ model implies $\mathrm{b}_{\mathrm{B}}=1$.

Figure 11 plots the between-industry component B(c) against the excess fraction of dropouts in each of the 150 larger MSA's. For reference, note that if changing industry structure accounted for the absorption of dropouts in cities with high dropout shares the points would lie along a line with slope 1. Although the points suggest an upward-sloping relationship, the slope is relatively modest, suggesting that changing industry structure accounts for only a small share of the absorption of dropouts. Indeed, the OLS estimate of $b_{B}$, reported in the first column of Table 6 , is 0.22 , and is significantly below 1 . By contrast, Figure 12 plots the within-industry component $\mathrm{W}(\mathrm{C})$ against the excess fraction of dropouts in each city. This component is more highly correlated with the dropout share, and many of the city observations are tightly clustered along the 45-degree line. The estimate of $b_{w}$, shown in column 2 of Table 6 , is 0.76 . Though not shown in a figure, the interaction terms are relatively small, and essentially uncorrelated with differences across cities in the share of dropout workers. Consistent with this, the estimate of $b_{\mathrm{I}}$ in column 3 of Table 4 is 0.02 (with a very small $\mathrm{R}$-squared $=0.03$ ).

The MSA's that show some evidence of significant between-industry adjustment are labeled in Figures 11 and 12. Interestingly, most of these MSA's are comprised of counties in California with substantial agricultural employment. Since agriculture relies on the availability of land resources, it is debatable whether variation in the employment share of agriculture represents a reaction to abundant supplies of less-educated labor. Rather, it seems more likely that the relative supplies of less-educated labor in these MSA's are driven by the availability of farm jobs.

The framework of equation (2) can be used to examine the contribution of the changing scale of specific industries to the absorption of local supplies of dropout labor. For example, the contribution of industry $i$ is $s^{\mathrm{d}}{ }_{\mathrm{i}}\left[\lambda_{\mathrm{i}}(\mathrm{c})-\lambda_{\mathrm{i}}\right]$, which is the excess employment share of the industry 
in city c relative to its national average share, multiplied by the average dropout intensity of the industry. Columns 4-6 of Table 6 show estimates of models similar to (4a), focusing on the absorption contributions of agriculture, textiles apparel and footwear industries, and a set of lowskilled service industries. ${ }^{21}$ The estimates suggest that these 3 industry clusters account for most of the between industry effect observed in column (1): agriculture alone accounts for nearly one-half. Figure 13 plots the between-industry component of absorption of dropout labor in different cities excluding agriculture, while Figure 14 shows the absorption contributions of agriculture industries and textiles and apparel industries. Overall, though there is some evidence that textiles and apparel manufacturing tends to cluster in cities with moderately high dropout shares, and that agricultural employment is higher in cities with very high dropout shares, the results in Table 6 and Figures 14 suggest that most of the absorption of unskilled labor across cities occurs within industries rather than between.

Similar conclusions were reached by Lewis (2003), who examined changes in the absorption of workers in 4 education groups over the 1980-1990 period. Lewis used Census data to estimate first-differenced versions of equation (3a) for each skill group. ${ }^{22}$ He also compared OLS estimates to IV estimates that used immigrant inflows based on historical immigration patterns as instruments for the changes in the relative shares of each skill group. As in the 2000 cross-section, the industry composition effects over the 1980-1990 period are only weakly related to local skill-group-specific population growth. Lewis' estimates of $\mathrm{b}_{\mathrm{B}}$ for manufacturing industries (which are arguably best

\footnotetext{
${ }^{21}$ We include textiles, apparel, knitting mills, footwear, and leather industries as apparel, and the following as "low skilled services": building services, landscaping services, carwashes, landscaping, dry cleaning and laundry services, private household services, and other personal services.

${ }^{22}$ One difference is that Lewis regresses the between-industry effects on the population share of the skill group in the local labor market, rather than the employment share. An advantage of a first differenced approach is that it eliminates the confounding caused by permanent factors like differences in the amount of agricultural land in an MSA.
} 
able to respond to local factor availability) are very close to 0 , while his estimates for all industries range from 0 to 0.08 . He also reports parallel specifications in which the dependent variable is the within-industry relative employment term. These are much more strongly correlated with relative population growth, accounting for 90 percent of the adjustment to skill-group specific relative supply shocks.

As a final exercise, we conducted a parallel analysis focusing on the absorption of Mexican immigrants. The relation between the within-industry absorption component and the share of Mexican workers in the local labor market is plotted in Figure 15, while regression models similar to the models for dropout workers are reported in columns 7-12 of Table 6 . The results reinforce our conclusions based on an analysis of dropout labor. In particular, over 90 percent of the adjustment to differences in the local availability of Mexican labor is explained by differences in the utilization of Mexican labor within 3-digit industries. Surprisingly, there is almost no evidence that availability of Mexican immigrant labor stimulates low-skill service employment.

Taken as a whole, the results in this section suggest that HO-style changes in industry structure play a relatively small role in explaining how cities have been able to absorb inflows of relatively unskilled Mexican immigrants over the 1990s. Contrary to our initial expectations, most of the inflows appear to be absorbed by city-specific within-industry increases in use of unskilled labor.

\section{c. Relative Wage Adjustments}

The observation that variation in the relative supply of dropout labor is mainly absorbed by changes in utilization within industries points to the potential importance of relative wage

adjustments in response to inflows of Mexican labor. We analyze relative wages in the framework of a conventional CES production function. The results in the last section suggest that we can ignore 
differences across industries and focus on a "one industry" model. Specifically, consider a production function for a single local output good:

$$
y=\left[\sum_{j}\left(e^{j} N^{j}\right)^{(\sigma-1) / \sigma}\right]^{\sigma /(\sigma-1)}
$$

where $\mathrm{N}^{j}$ is the number of people employed in skill group $j, \mathrm{e}^{\mathrm{j}}$ is a relative productivity shock, and $\sigma$ is the elasticity of substitution between labor types. Given a set of wage rates w ${ }^{j}$ for different skill groups, the relative labor demand curve between any two skill groups, say $\mathrm{d}=$ dropout labor and $\mathrm{H}=$ high school graduate labor, can be written as

$$
\log \left(\mathrm{N}^{\mathrm{d}} / \mathrm{N}^{\mathrm{H}}\right)=-\sigma \log \left(\mathrm{w}^{\mathrm{d}} / \mathrm{w}^{\mathrm{H}}\right)+(\boldsymbol{\sigma}-1) \log \left(\mathrm{e}^{\mathrm{d}} / \mathrm{e}^{\mathrm{H}}\right) .
$$

This equation shows that employers can be induced to increase the relative utilization of dropout labor by reducing the relative wage of dropout workers. Inverting the relative demand curve leads to a simple estimating equation that relates the relative wage gap between high school graduates and dropouts in a city to the relative supply of the two types of workers:

$$
\log \left(\mathrm{w}^{\mathrm{H}} / \mathrm{w}^{\mathrm{d}}\right)=-1 / \sigma \log \left(\mathrm{N}^{\mathrm{H}} / \mathrm{N}^{\mathrm{d}}\right)-(\boldsymbol{\sigma}-1) / \sigma \log \left(\mathrm{e}^{\mathrm{H}} / \mathrm{e}^{\mathrm{d}}\right) .
$$

As has been recognized in the immigration literature, a problem for the estimation of a model like (4) is that local relative demand shocks may raise relative wages and attract differential inflows of skilled versus unskilled workers. To address this concern, we consider a first-differenced version of (4) that abstracts from any permanent characteristics of a city that may affect the relative demand for less-skilled labor. We also consider IV estimates of the first differenced model, in which we use the supply push variables (lagged Mexican immigrant densities in the city) to instrument the change in the relative supply of dropout labor in a city.

Table 7 presents estimation results for equation (4), based on data for 145 larger MSA's. We measure the dependent variable as the difference between regression-adjusted mean log wages for native male workers in a city with exactly 12 years of schooling, and those with less than 12 years of 
schooling. Following the recent inequality literature (e.g., Katz and Murphy, 1992) we measure the supply of high school workers in a city by the number of people with a high school diploma, plus $1 / 2$ of the number who have between 13 and 15 years of completed schooling. We similarly measure the supply of dropout workers as a simple count of the number with less than a high school education. The models are estimated by weighed OLS and IV, using 1990 population counts as weights.

The results for the OLS models in columns 1-3 suggest that there is not a large or statistically significant relationship between the relative wages of high school dropouts and their relative supply in different cities, although the point estimate of the relative supply effect in the firstdifferenced model is negative. We also consider a specification in column 4 that adds employment growth in the city as an additional explanatory variable. This has a modest negative effect on the wage gap, suggesting that relative wages of dropouts are higher in rapidly growing cities, though the coefficient is not significant at conventional levels. Adding this variable has little impact on the estimated supply effect.

Before turning to the IV results it is instructive to look at the data in Figures 16 and 17, which illustrate the relationship between inflows of new Mexican immigrants to a city and the relative supply (Figure 16) and relative wages (Figure 17) of dropout labor. Figure 16 establishes that there is a strong impact of Mexican inflows on the relative supply of dropout versus high school labor. Given the models in Table 4 suggesting that much of the variation in Mexican inflows can be explained by supply push factors, there is a strong presumption that our IV strategy will have a reasonable "first stage". Figure 17, on the other hand, suggests that there is not much correlation between high-school/dropout wage gap and the inflow rate of Mexican immigrants. The overall scatter of the points is slightly positively sloping (consistent with the idea that an increase in the 
relative supply of dropouts lowers their relative wages), but close inspection suggests that only a handful of points contribute to the slope.

The simple IV specification in column (5) of Table 7 yields an estimate of the effect of relative supply that is somewhat less precise than the corresponding OLS model, but no more negative in magnitude. The same conclusion emerges from the model in column 6 , in which we treat both the change in relative supply and employment growth as endogenous. It does not appear that increasing supplies of dropout labor arising from the predictable component of inflows of Mexican immigrants have much effect on the relative wage structure in a city.

We have also estimated a number of variants of the models in Table 7 . In one variant, we added a control for the change in the relative number of college versus high-school educated workers to the first-differenced specification in column 4. This variable has a marginally significant positive effect on the high-school-dropout wage gap (coefficient $=0.15$, standard error $=0.07$ ) but its addition does not have any impact on the coefficient of the variable measuring the relative supply of dropouts, or on the employment growth effect. We also estimated the models using unweighted OLS and IV. The coefficient estimates from the unweighted models are somewhat less precise, but show a similar pattern to the results in Table 7. For example, the estimated relative supply effect from the first-differenced specification (4) is -0.07 (with a standard error of 0.05 ). Finally, we considered a specification in which the supply of high school workers was narrowly defined to include only those with exactly 12 years of schooling. This leads to a slightly bigger coefficient on the relative supply variable. For example, the estimate corresponding to the specification in column 4 is -0.06 , with a standard error of 0.04 . Overall, there is not much evidence that the relative supply of dropout labor in a city has much impact on dropout relative wages. 


\section{d. Interpretation}

Taken as a whole, our findings with respect to the impacts of Mexican immigration present a puzzle. Inflows of Mexican immigrants appear to raise the relative supply of low-education labor in a city. Contrary to a simple trade-style model, however, shifts in the in relative supply of loweducation labor across cities do not lead to systematic expansions or contractions in dropoutintensive industries. Rather, most of the variation in the relative supply of dropout labor is absorbed by changes in dropout intensity within narrowly defined industries. Even more surprisingly, differences in dropout intensity of employment do not seem to be strongly related to the relative wages of dropout workers. Thus, it is hard to explain the variation in dropout intensity across cities as variation along a relative demand curve.

We believe there are (at least) two possible explanations for these findings. One is that dropout workers - and Mexican immigrants in particular - are close to perfect substitutes for highschool educated workers. If this is true, then inflows of Mexican immigrants affect relative wages for a much broader group than just high school dropouts. Further work is needed to carefully examine the effects of Mexican immigration on the broader wage structure. The proportional impacts of Mexican inflows on the relative supply of labor with up to 12 years of schooling (or even up to 15 years of schooling) are considerably smaller than their impacts on the relative supply of dropout labor, so if this hypothesis is true, concerns over the negative impacts of Mexican immigrants on low-wage natives may be overstated.

A second possibility is that employers adapt to the relative supply of different skill groups in their local market without the "signals" of relative wage changes. Acemoglu's (1998) model of endogenous technological change, for example, suggests that firms will innovate in a direction to take advantage of more readily available factors, even in the absence of relative wage changes. Lewis 
(2004) presents some direct evidence for an endogenous technological change mechanism, using

data on the number of advanced technologies adopted by manufacturing plants in the late 1980s and early 1990s. He finds that controlling for very detailed (4 digit) industry effects, the adoption of advanced technologies by individual plants is significantly slowed by the presence of a greater relative supply of unskilled labor in the local labor market. More work is needed to understand how firms choose which technologies to use, and whether the choice is influenced by the relative availability of different skill groups, particularly low-skilled immigrants.

\section{Conclusions}

Mexicans are the largest single group of immigrants in the U.S., representing about one-third of all immigrants and more than $4 \%$ of the country's working age population. Until the last decade, Mexican immigrants were geographically clustered in a relatively small number of cities. In 1990, nearly a half of all working age Mexicans were living in just 5 U.S. cities, and 70 percent were living in only 15 cities. During the 1990s, however, arrivals from Mexico established sizeable immigrant communities in many "new" cities, including Atlanta, Denver, Portland, and Raleigh-Durham. These immigrants are changing the face of the new destination cities and setting the stage for many years of future inflows.

In this paper we present some simple evidence on the causes and consequences of the widening geographic diffusion of Mexican immigrants. A combination of demand-pull and supply push factors explains $85 \%$ of the variation across major cities in the rate of Mexican inflows during the 1990s, and helps illuminate the single most important trend in the destination choices of new Mexican immigrants - the move away from Los Angeles.

Like their predecessors, recent Mexican immigrants have relatively low levels of education. 
We show that inflows of Mexican immigrants lead to systematic shifts in the relative supply of loweducation labor in a city, opening up the question of how different local labor markets are adopting to substantial differences in relative supply. One possibility - suggested by the conventional Hecksher Olin model of international trade - is that these differences are accommodated by shifts in industry composition. Despite the theoretical appeal of this hypothesis, we find it has limited empirical relevance: most of the differences across cities in the relative supply of low-education labor (or Mexican labor) are absorbed by changes in skill intensity within narrow industries. Such adjustments could be readily explained if Mexican immigrant inflows had large effects on the relative wage structures of different cities. As has been found in previous studies of the local impacts of immigration, however, our analysis suggests that relative wage adjustments are small. Thus, we are left with the "puzzle" of explaining the remarkable flexibility of employment demand in different cities to local variation in supply. Given the continuing pace of Mexican immigration, the next decade should provide even more evidence on the ways that local economies adjust to shifts in relative supply. 


\section{References}

Acemoglu, Daron. "Why Do New Technologies Complement Skills? Directed Technical Change and Wage Inequality.” Quarterly Journal of Economics 114 (November 1998): 1055-1089.

Altonji, Joseph G., and David Card "The effects of immigration on the labor market outcomes of less-skilled natives". In John M. Abowd and Richard B. Freeman, eds., Immigration, Trade, and the Labor Market. Chicago: The University of Chicago Press, 1991.

Bartel, Anne. "Where Do the New U.S. Immigrants Live?” Journal of Labor Economics 7 (October 1989): 371-391.

Borjas, George, Richard B. Freeman, and Kevin Lang. "Undocumented Mexican-born Workers in the United States: How Many, How Permanent? In John M. Abowd and Richard B. Freeman, eds., Immigration, Trade, and the Labor Market. Chicago: The University of Chicago Press, 1991.

Card, David. "Immigrant Inflows, Native Outflows and the Local Labor Market Impacts of Higher Immigration." Journal of Labor Economics, 19 (January 2001).

Card, David. "Is the New Immigration Really So Bad?" IZA Discussion Paper \#1119, Bonn: IZA, April 2004.

Card, David and John E. DiNardo. “Do Immigrant Inflows Lead to Native Outflows?” American Economic Review 90 (May 2000).

Katz, Lawrence and Kevin M. Murphy. "Changes in Relative Wages, 1963-1987: Supply and Demand Factors.” Quarterly Journal of Economics 107 (February 1992): 35-78.

Lewis, Ethan G. "Local Open Economies within the U.S. How do Industries Respond to Immigration?” Federal Reserve Bank of Philadelphia Working Paper (December 2003).

Lewis, Ethan G. " The Effect of Local Skill Mix on New Technology Adoption in U.S. Manufacturing." Federal Reserve Bank of Philadelphia Unpublished Working Paper (December 2004).

Norwood, Janet et. al. The 2000 Census: Counting Under Adversity. Washington DC: National Academy of Sciences, 2004.

Organization for Economic Co-operation and Development. OECD Economic Surveys 1999-2000: Mexico. Paris: OECD, 2000.

Passel, Jeffrey. "New Estimates of the the Undocumented Population in the United States." Migration Information Source. Washington DC: Migration Policy Institute, May 2002.

United States Department of Citizenship and Immigration Services. "Estimates of the 
Unauthorized Immigrant Population Residing in the United States: 1990 to 2000.” Unpublished Paper Dated January 2003. Available at:

http://uscis.gov/graphics/shared/aboutus/statistics/Ill_Report_1211.pdf .

Van Hook, Jennifer and Frank D. Bean. "Estimating Underenumeration Among Unauthorized Mexican Migrants to the United States: Applications of Mortality Analyses." In Mexican Ministry of Foreign Affairs and U.S. Commission on Immigration Reform, Migration Between Mexico and the United States, Research Reports and Background Materials. Mexico City and Washington DC: Mexican Ministry of Foreign Affairs and U.S. Commission on Immigration Reform. 1998. 
Table 1: Characteristics of Mexican Immigrants in 1980, 1990, and 2000

\begin{tabular}{|c|c|c|c|}
\hline & 1980 & 1990 & 2000 \\
\hline Percent Female & 46.5 & 44.2 & 43.7 \\
\hline \multicolumn{4}{|l|}{ Age Distribution: } \\
\hline Percent Under 30 & 47.2 & 45.5 & 39.9 \\
\hline Percent 31-50 & 40.9 & 44.2 & 49.2 \\
\hline Percent 31-50 & 11.9 & 10.3 & 10.9 \\
\hline \multicolumn{4}{|l|}{ Distribution of Years in US: } \\
\hline $0-5$ Years & 30.0 & 26.3 & 25.0 \\
\hline $6-10$ Years & 25.2 & 20.0 & 19.1 \\
\hline 10 or more Years & 44.7 & 53.6 & 55.9 \\
\hline \multicolumn{4}{|l|}{ Education: } \\
\hline Percent $<12$ Years Schooling & 76.7 & 74.6 & 70.2 \\
\hline Mean Years of Schooling & 7.4 & 8.1 & 8.4 \\
\hline Percent Low English Ability & 54.6 & 50.3 & 52.3 \\
\hline \multicolumn{4}{|l|}{ Geographic Distribution: } \\
\hline Percent in California & 58.0 & 58.4 & 44.9 \\
\hline Percent in Texas & 22.2 & 21.2 & 19.5 \\
\hline Percent in MSA & 92.8 & 91.3 & 90.1 \\
\hline \multicolumn{4}{|l|}{ Labor Market Outcomes: } \\
\hline \multicolumn{4}{|l|}{ Percent Employed Last Year: } \\
\hline Men & 85.9 & 85.7 & 83.9 \\
\hline Women & 49.4 & 53.7 & 52.9 \\
\hline \multicolumn{4}{|l|}{ Mean Hourly Wage (1999\$) } \\
\hline Men & 14.22 & 11.61 & 12.89 \\
\hline Women & 11.06 & 9.68 & 11.07 \\
\hline \multicolumn{4}{|l|}{ Mean Log Wage Gap Relative } \\
\hline Men & -30.6 & -42.6 & -41.2 \\
\hline Women & -17.0 & -29.5 & -33.2 \\
\hline $\begin{array}{l}\text { Percent of Total Population } \\
\text { (Age 16-65) }\end{array}$ & 1.13 & 2.16 & 4.11 \\
\hline Sample Size & 83,628 & 174,364 & 373,909 \\
\hline
\end{tabular}

Notes: Based on tabulations of 1980-2000 Censuses. 
Table 2: Geographic Concentration of Mexican Immigrants

\begin{tabular}{|c|c|c|c|}
\hline & 1980 & 1990 & 2000 \\
\hline \multicolumn{4}{|c|}{ Percent of Mexican Immigrants (Age 16-65) Living In: } \\
\hline Los Angeles & 31.7 & 27.9 & 17.4 \\
\hline Chicago & 7.9 & 5.4 & 5.5 \\
\hline Houston & 4.4 & 4.1 & 4.4 \\
\hline Orange County $\mathrm{Ca}$ & 4.1 & 6.0 & 4.7 \\
\hline San Diego & 3.9 & 4.1 & 3.1 \\
\hline El Paso & 3.9 & 2.7 & 1.6 \\
\hline San Fransisco/Oakland & 2.5 & 2.3 & 2.4 \\
\hline Dallas/Fort Worth & 2.3 & 3.3 & 4.7 \\
\hline McAllen & 2.1 & 1.7 & 1.5 \\
\hline San Antonio & 2.0 & 1.5 & 1.1 \\
\hline San Jose & 1.7 & 1.7 & 1.5 \\
\hline Brownsville & 1.6 & 1.9 & 0.8 \\
\hline Ventura County Ca & 1.6 & 1.4 & 1.1 \\
\hline Fresno & 1.4 & 1.6 & 1.6 \\
\hline Riverside/San Bernardino Ca & 1.3 & 4.1 & 4.1 \\
\hline Share of Top 5 & 51.9 & 47.5 & 35.1 \\
\hline Share of Top 15 & 72.3 & 69.7 & 55.5 \\
\hline
\end{tabular}

Notes: Based on tabulations of 1980-2000 Censuses.

City definitions correspond to 1980 definitions. 
Table 3: Growth in Overall and Mexican Immigrant Populations, 1990 to 2000

\begin{tabular}{|c|c|c|c|c|c|c|c|c|}
\hline & & & & \multicolumn{5}{|c|}{ Changes from 1990 to $2000:$} \\
\hline & \multicolumn{3}{|c|}{ Working Age Population in 1990} & \multirow{2}{*}{$\begin{array}{l}\text { Adult } \\
\text { Population } \\
\text { Growth } \\
(\%) \\
\end{array}$} & \multirow{2}{*}{$\begin{array}{l}\text { Mexican } \\
\text { Immigrant } \\
\text { Growth } \\
(\%)\end{array}$} & \multirow{2}{*}{$\begin{array}{c}\text { Growth in } \\
\text { Number } \\
\text { Mex Imms }\end{array}$} & \multirow{2}{*}{$\begin{array}{l}\text { Cumulative } \\
\text { Percent of } \\
\text { Total Rise }\end{array}$} & \multirow{2}{*}{$\begin{array}{l}\text { Number o } \\
\text { Post-1990 } \\
\text { Mex Imms }\end{array}$} \\
\hline & Total & $\begin{array}{c}\text { Mexican } \\
\text { Immigrants }\end{array}$ & $\begin{array}{l}\text { Percent } \\
\text { Mex Imms }\end{array}$ & & & & & \\
\hline 1 Los Angeles & $5,785,200$ & 973,120 & 16.8 & 5.8 & 33.5 & 326,260 & 9.5 & 413,140 \\
\hline 2 Chicago & $4,170,420$ & 186,800 & 4.5 & 9.8 & 119.8 & 223,800 & 15.9 & 182,560 \\
\hline 3 Phoenix & $1,268,280$ & 52,400 & 4.1 & 62.1 & 363.9 & 190,700 & 21.5 & 135,640 \\
\hline 4 Dallas & $1,693,060$ & 85,320 & 5.0 & 36.6 & 215.6 & 183,960 & 26.8 & 153,240 \\
\hline 5 Houston & $1,908,400$ & 137,320 & 7.2 & 26.2 & 131.3 & 180,300 & 32.0 & 147,220 \\
\hline 6 Riverside/SB Ca & $1,444,480$ & 142,620 & 9.9 & 27.8 & 112.6 & 160,560 & 36.6 & 89,860 \\
\hline 7 Orange County & $1,687,500$ & 208,000 & 12.3 & 13.1 & 69.7 & 144,900 & 40.8 & 139,200 \\
\hline 8 Los Vegas & 470,200 & 15,240 & 3.2 & 113.4 & 615.8 & 93,840 & 43.6 & 52,360 \\
\hline 9 San Diego & $1,603,060$ & 144,440 & 9.0 & 11.1 & 63.0 & 90,980 & 46.2 & 74,960 \\
\hline 10 Atlanta & $1,757,700$ & 7,320 & 0.4 & 41.7 & 1076.5 & 78,800 & 48.5 & 66,180 \\
\hline 11 New York City & $4,520,040$ & 28,140 & 0.6 & 13.8 & 270.2 & 76,020 & 50.7 & 67,040 \\
\hline 12 Denver & $1,018,560$ & 12,620 & 1.2 & 25.5 & 585.4 & 73,880 & 52.8 & 54,260 \\
\hline 13 Oakland & $1,379,320$ & 46,500 & 3.4 & 13.7 & 152.2 & 70,780 & 54.9 & 52,780 \\
\hline 14 Fresno & 396,560 & 54,320 & 13.7 & 41.4 & 113.7 & 61,780 & 56.7 & 45,260 \\
\hline 15 Fort Worth & 920,880 & 30,240 & 3.3 & 10.6 & 178.3 & 53,920 & 58.2 & 41,700 \\
\hline 16 Austin Tx & 518,400 & 16,060 & 3.1 & 60.9 & 322.0 & 51,720 & 59.7 & 36,900 \\
\hline 17 San Jose & $1,048,420$ & 59,660 & 5.7 & 8.0 & 86.0 & 51,280 & 61.2 & 49,380 \\
\hline 18 McAllen Tx & 202,860 & 60,960 & 30.1 & 45.5 & 84.1 & 51,240 & 62.7 & 35,900 \\
\hline 19 Tulare County Ca & 171,560 & 31,800 & 18.5 & 67.4 & 154.3 & 49,080 & 64.1 & 28,800 \\
\hline 20 Montery County Ca & 224,860 & 36,000 & 16.0 & 43.2 & 131.5 & 47,340 & 65.5 & 31,420 \\
\hline 21 Bakersfield & 318,120 & 32,480 & 10.2 & 22.4 & 124.8 & 40,540 & 66.6 & 25,060 \\
\hline 22 Portland & 885,080 & 9,320 & 1.1 & 35.1 & 424.3 & 39,540 & 67.8 & 30,820 \\
\hline 23 Ventura County $\mathrm{Ca}$ & 437,260 & 48,200 & 11.0 & 9.3 & 76.8 & 37,020 & 68.9 & 28,920 \\
\hline 24 San Francisco & $1,030,900$ & 32,720 & 3.2 & 12.6 & 91.0 & 29,760 & 69.7 & 28,740 \\
\hline 25 Raleigh-Durham & 469,180 & 880 & 0.2 & 78.0 & 3156.8 & 27,780 & 70.5 & 23,360 \\
\hline 26 San Antonio & 841,060 & 51,400 & 6.1 & 4.2 & 53.4 & 27,420 & 71.3 & 26,240 \\
\hline 27 El Paso & 351,640 & 93,900 & 26.7 & 5.2 & 28.3 & 26,580 & 72.1 & 32,140 \\
\hline 28 Greensboro NC & 729,680 & 1,140 & 0.2 & 8.8 & 2287.7 & 26,080 & 72.8 & 21,420 \\
\hline 29 Salt Lake City & 575,160 & 3,700 & 0.6 & 23.4 & 670.3 & 24,800 & 73.6 & 18,960 \\
\hline 30 Sacramento & 941,920 & 22,040 & 2.3 & 6.6 & 112.4 & 24,780 & 74.3 & 19,200 \\
\hline 31 Santa Barbara & 251,580 & 27,460 & 10.9 & 15.5 & 88.1 & 24,200 & 75.0 & 21,640 \\
\hline 32 Tucson & 399,780 & 23,880 & 6.0 & 28.7 & 100.8 & 24,060 & 75.7 & 16,900 \\
\hline 33 Seattle & $1,204,960$ & 3,360 & 0.3 & 18.0 & 695.8 & 23,380 & 76.4 & 17,140 \\
\hline 34 Washington DC & $2,610,900$ & 7,860 & 0.3 & 25.1 & 271.3 & 21,320 & 77.0 & 18,260 \\
\hline 35 Stockton $\mathrm{Ca}$ & 298,380 & 26,380 & 8.8 & 19.5 & 79.9 & 21,080 & 77.6 & 18,800 \\
\hline 36 Charlotte NC & 785,040 & 900 & 0.1 & 12.7 & 2313.3 & 20,820 & 78.2 & 17,660 \\
\hline 37 Yuma Az & 59,120 & 12,920 & 21.9 & 59.5 & 158.5 & 20,480 & 78.8 & 10,600 \\
\hline 38 Modesto $\mathrm{Ca}$ & 231,440 & 21,460 & 9.3 & 22.0 & 91.4 & 19,620 & 79.3 & 13,420 \\
\hline 39 Santa Rosa & 224,040 & 8,840 & 4.0 & 40.2 & 217.7 & 19,240 & 79.9 & 13,700 \\
\hline 40 Vallejo $\mathrm{Ca}$ & 302,080 & 11,560 & 3.8 & 10.2 & 159.2 & 18,400 & 80.4 & 13,500 \\
\hline
\end{tabular}


Table 4: Regression Models for Growth in Recent Mexican Immigrant Population

\begin{tabular}{|c|c|c|c|c|c|c|c|}
\hline & \multicolumn{4}{|c|}{ Estimated by OLS } & \multicolumn{3}{|c|}{ Estimated by IV } \\
\hline & $(1)$ & $(2)$ & (3) & (4) & (5) & (6) & $(7)$ \\
\hline Mexican Population Share, 1990 & $\begin{array}{r}1.33 \\
(0.12)\end{array}$ & -- & $\begin{array}{r}1.34 \\
(0.09)\end{array}$ & $\begin{array}{r}1.34 \\
(0.09)\end{array}$ & -- & $\begin{array}{r}1.34 \\
(0.09)\end{array}$ & $\begin{array}{r}1.34 \\
(0.09)\end{array}$ \\
\hline Mexican Population Share, 1980 & $\begin{array}{r}-1.16 \\
(0.18)\end{array}$ & -- & $\begin{array}{r}-1.18 \\
(0.14)\end{array}$ & $\begin{array}{r}-1.18 \\
(0.14)\end{array}$ & -- & $\begin{array}{r}-1.18 \\
(0.14)\end{array}$ & $\begin{array}{l}-1.18 \\
(0.14)\end{array}$ \\
\hline Employment Growth, 1990-2000 & -- & $\begin{array}{r}0.09 \\
(0.02)\end{array}$ & $\begin{array}{r}0.07 \\
(0.01)\end{array}$ & $\begin{array}{r}0.08 \\
(0.01)\end{array}$ & $\begin{array}{r}0.12 \\
(0.03)\end{array}$ & $\begin{array}{r}0.07 \\
(0.01)\end{array}$ & $\begin{array}{r}0.07 \\
(0.01)\end{array}$ \\
\hline $\begin{array}{l}\text { Mean Log Wage of Mexican } \\
\text { Men in } 1990(x 100)\end{array}$ & -- & -- & -- & $\begin{array}{r}0.47 \\
(0.43)\end{array}$ & -- & -- & $\begin{array}{r}0.35 \\
(0.45)\end{array}$ \\
\hline $\begin{array}{l}\text { Relative Employment Rate of } \\
\text { Mexican Men in } 1990(x 100)\end{array}$ & -- & -- & -- & $\begin{array}{r}-0.12 \\
(1.10)\end{array}$ & -- & -- & $\begin{array}{r}-0.06 \\
(1.16)\end{array}$ \\
\hline R-squared & 0.78 & 0.11 & 0.86 & 0.86 & 0.10 & 0.86 & 0.86 \\
\hline First Stage F-statistic ( 9 d.f.) & -- & -- & -- & -- & 13.40 & 14.81 & 13.06 \\
\hline
\end{tabular}

Notes: All models estimated on sample of 142 larger cities with Census data for 1980-2000, and matching employment data from County Business Patterns for 1982-2000. Dependent variable is number of recent (post-1990) adult Mexican immigrants in city in 2000, divided by population in 1990. Instruments for employment growth 1990-2000 are log employment counts in 1982-1990. Mean log wage and relative employment rate for city in 1990 are regression adjusted for characteristics of Mexican male workers in the cty. 
Table 5: Regression Models for Level or Change in Fraction of Dropouts in Local Population

\begin{tabular}{|c|c|c|c|c|c|}
\hline & \multirow{2}{*}{\multicolumn{2}{|c|}{$\begin{array}{l}\text { Models for Fraction of } \\
\text { Dropouts in 2000: } \\
\text { Estimated by OLS }\end{array}$}} & \multicolumn{3}{|c|}{$\begin{array}{l}\text { Models for Change in Fraction of } \\
\text { Dropouts Between } 1990 \text { and 2000: }\end{array}$} \\
\hline & & & \multicolumn{2}{|c|}{ Estimated by OLS } & \multirow{2}{*}{$\frac{\mathrm{IV}}{(5)}$} \\
\hline & $(1)$ & $(2)$ & $(3)$ & $(4)$ & \\
\hline $\begin{array}{l}\text { Relative Growth in "New" (Post-1990) Mexican } \\
\text { Immigrants (1990-2000) }\end{array}$ & $\begin{array}{r}1.29 \\
(0.11)\end{array}$ & $\begin{array}{r}0.89 \\
(0.19)\end{array}$ & $\begin{array}{r}0.49 \\
(0.04)\end{array}$ & $\begin{array}{r}0.49 \\
(0.10)\end{array}$ & $\begin{array}{r}0.52 \\
(0.05)\end{array}$ \\
\hline $\begin{array}{l}\text { Relative Growth in "New" (Post-1980) Mexican } \\
\text { Immigrants (1980-1990) }\end{array}$ & -- & $\begin{array}{r}0.69 \\
(0.20)\end{array}$ & -- & $\begin{array}{r}0.01 \\
(0.10)\end{array}$ & -- \\
\hline Employment Growth, 1990-2000 & -- & $\begin{array}{r}-0.09 \\
(0.03)\end{array}$ & -- & $\begin{array}{r}0.00 \\
(0.01)\end{array}$ & $\begin{array}{r}0.02 \\
(0.01)\end{array}$ \\
\hline R-squared & 0.51 & 0.64 & 0.44 & 0.44 & 0.41 \\
\hline
\end{tabular}

Notes: All models estimated on sample of 144 larger cities with Census data for 1980-2000, and matching employment data from County Business Patterns for 1982-2000. Dependent variable is fraction of dropouts in adult population in city in 2000 (columns 1-2) or the change in the fraction of dropouts in the adult population from 1990 to 2000 (columns 3-5). Model in column (5) is estimated by instrumental variables, using as instruments the fraction of Mexicans in the city in 1980 and 1990 and the log of employment in the MSA in 1982-1990. 
Table 6: Regression Models Measuring Cross-City Absorption of Excess Dropout Workers or Mexican Immigrants

\begin{tabular}{|c|c|c|c|c|c|c|c|c|c|c|c|c|}
\hline & \multicolumn{6}{|c|}{ Absorption of Excess Fraction of Dropout Workers: } & \multicolumn{6}{|c|}{ Absorption of Excess Fraction of Mexican Immigrants: } \\
\hline & $\begin{array}{l}\text { Within } \\
\text { Industry } \\
(1)\end{array}$ & $\begin{array}{c}\text { Between } \\
\text { Industry } \\
(2) \\
\end{array}$ & $\begin{array}{l}\text { Inter- } \\
\text { action } \\
(3) \\
\end{array}$ & $\begin{array}{c}\text { Sector-S } \\
\text { Agricult. } \\
(4)\end{array}$ & $\begin{array}{c}\text { pecific Ab } \\
\text { Textiles } \\
\text { Apparel } \\
(5)\end{array}$ & $\begin{array}{c}\text { sorption: } \\
\text { Low-Skill } \\
\text { Services } \\
(6)\end{array}$ & $\begin{array}{c}\text { Within } \\
\text { Industry } \\
(7)\end{array}$ & $\begin{array}{c}\text { Between } \\
\text { Industry } \\
(8)\end{array}$ & $\begin{array}{r}\text { Inter- } \\
\text { action } \\
(9) \\
\end{array}$ & $\begin{array}{c}\text { Sector-S } \\
\text { Agricult. } \\
(10)\end{array}$ & $\begin{array}{c}\text { pecific } A b \\
\text { Textiles } \\
\text { Apparel } \\
(11) \\
\end{array}$ & $\begin{array}{c}\text { sorption: } \\
\text { Low-Skill } \\
\text { Services } \\
(12) \\
\end{array}$ \\
\hline $\begin{array}{l}\text { Excess Fraction of } \\
\text { Dropouts or Mexican } \\
\text { Immigrants }\end{array}$ & $\begin{array}{r}0.76 \\
(0.02)\end{array}$ & $\begin{array}{r}0.22 \\
(0.02)\end{array}$ & $\begin{array}{r}0.02 \\
(0.01)\end{array}$ & $\begin{array}{r}0.09 \\
(0.02)\end{array}$ & $\begin{array}{r}0.05 \\
(0.01)\end{array}$ & $\begin{array}{r}0.03 \\
(0.01)\end{array}$ & $\begin{array}{r}0.92 \\
(0.01)\end{array}$ & $\begin{array}{r}0.06 \\
(0.01)\end{array}$ & $\begin{array}{r}0.01 \\
(0.01)\end{array}$ & $\begin{array}{r}0.04 \\
(0.01)\end{array}$ & $\begin{array}{r}0.01 \\
(0.00)\end{array}$ & $\begin{array}{r}0.01 \\
(0.00)\end{array}$ \\
\hline R-squared & 0.84 & 0.37 & 0.03 & 0.17 & 0.24 & 0.33 & 0.96 & 0.25 & 0.01 & 0.14 & 0.13 & 0.41 \\
\hline
\end{tabular}

Note: All models estimated across 150 larger cities, using 264 industry cells per city. Regressions are weighted by city size. 
Table 7: Regression Models for Wage Gap Between High School and Dropout Native Male Workers

\begin{tabular}{|c|c|c|c|c|c|c|}
\hline & \multicolumn{4}{|c|}{ Estimated by OLS } & \multicolumn{2}{|c|}{$\begin{array}{c}\text { Estimated by IV } \\
\text { Change: } 1990-2000\end{array}$} \\
\hline & $\begin{array}{c}2000 \\
(1) \\
\end{array}$ & $\begin{array}{c}1990 \\
(2)\end{array}$ & $\begin{array}{c}\text { Change: } \\
(3)\end{array}$ & $\begin{array}{r}2000 \\
(4) \\
\end{array}$ & $\begin{array}{c}\text { Change: } \\
(5)\end{array}$ & $\begin{array}{r}2000 \\
(6) \\
\end{array}$ \\
\hline $\begin{array}{l}\text { Log Relative Supply (High School } \\
\text { vs. Dropout Labor) }\end{array}$ & $\begin{array}{r}0.01 \\
(0.01)\end{array}$ & $\begin{array}{r}-0.03 \\
(0.01)\end{array}$ & $\begin{array}{r}-0.04 \\
(0.04)\end{array}$ & $\begin{array}{r}-0.05 \\
(0.04)\end{array}$ & $\begin{array}{r}0.00 \\
(0.07)\end{array}$ & $\begin{array}{r}-0.04 \\
(0.06)\end{array}$ \\
\hline Employment Growth, 1990-2000 & -- & -- & -- & $\begin{array}{r}-0.06 \\
(0.04)\end{array}$ & -- & $\begin{array}{r}-0.01 \\
(0.05)\end{array}$ \\
\hline R-squared & 0.00 & 0.04 & 0.01 & 0.02 & 0.00 & 0.00 \\
\hline
\end{tabular}

Notes: All models estimated on sample of 145 larger cities with Census data for 1980-2000, and matching employment data from County Business Patterns for 1982-2000. Dependent variable is gap between regression adjusted mean log wage of high school male natives in city and regression adjusted mean log wage of dropout male natives in city. Instruments in column (5) are fraction Mexican immigrants in adult population of city in 1980 and 1990. Instruments in column (6) are fraction of Mexican immigrants in adult population in 1980 and 1990, and log of city-level employment in 1982-1990. 
Figure 1: Number and Location of Mexican Immigrants, By Arrival Year

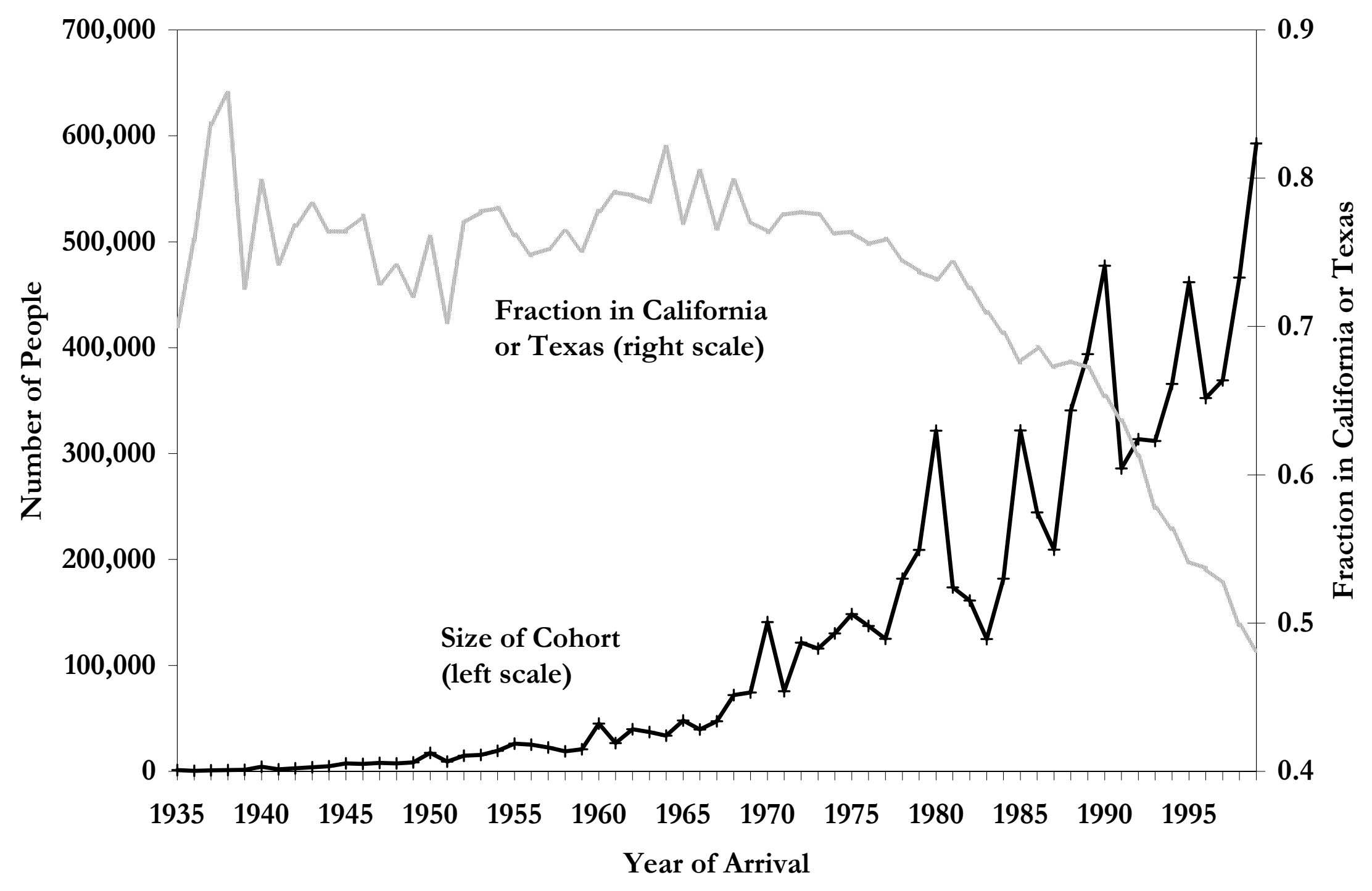


Figure 2: Growth in Mexican Immigrant Population: Recent Arrivals and Total Change

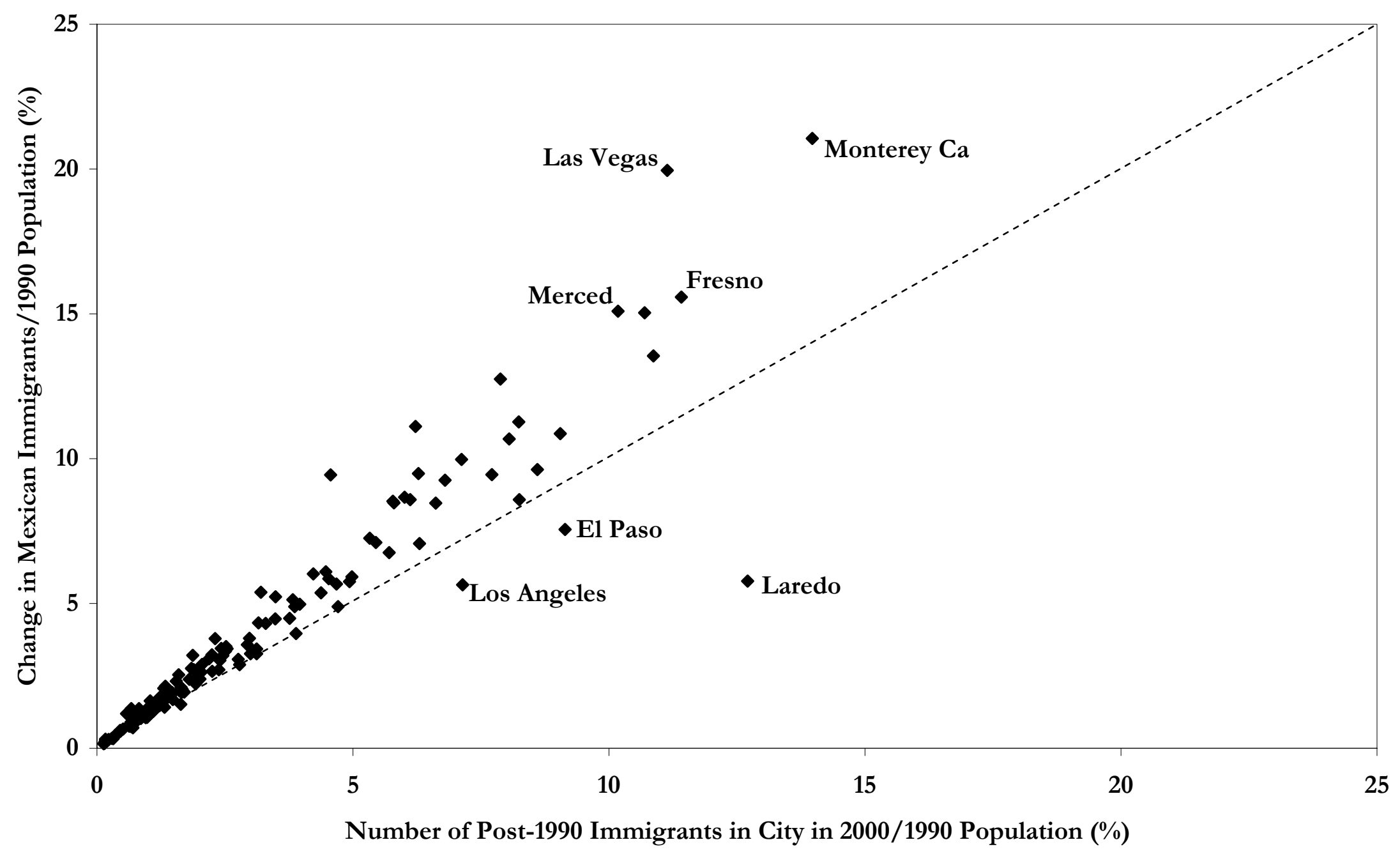


Figure 3: Location of Mexican Immigrants, by Years Since Arrival

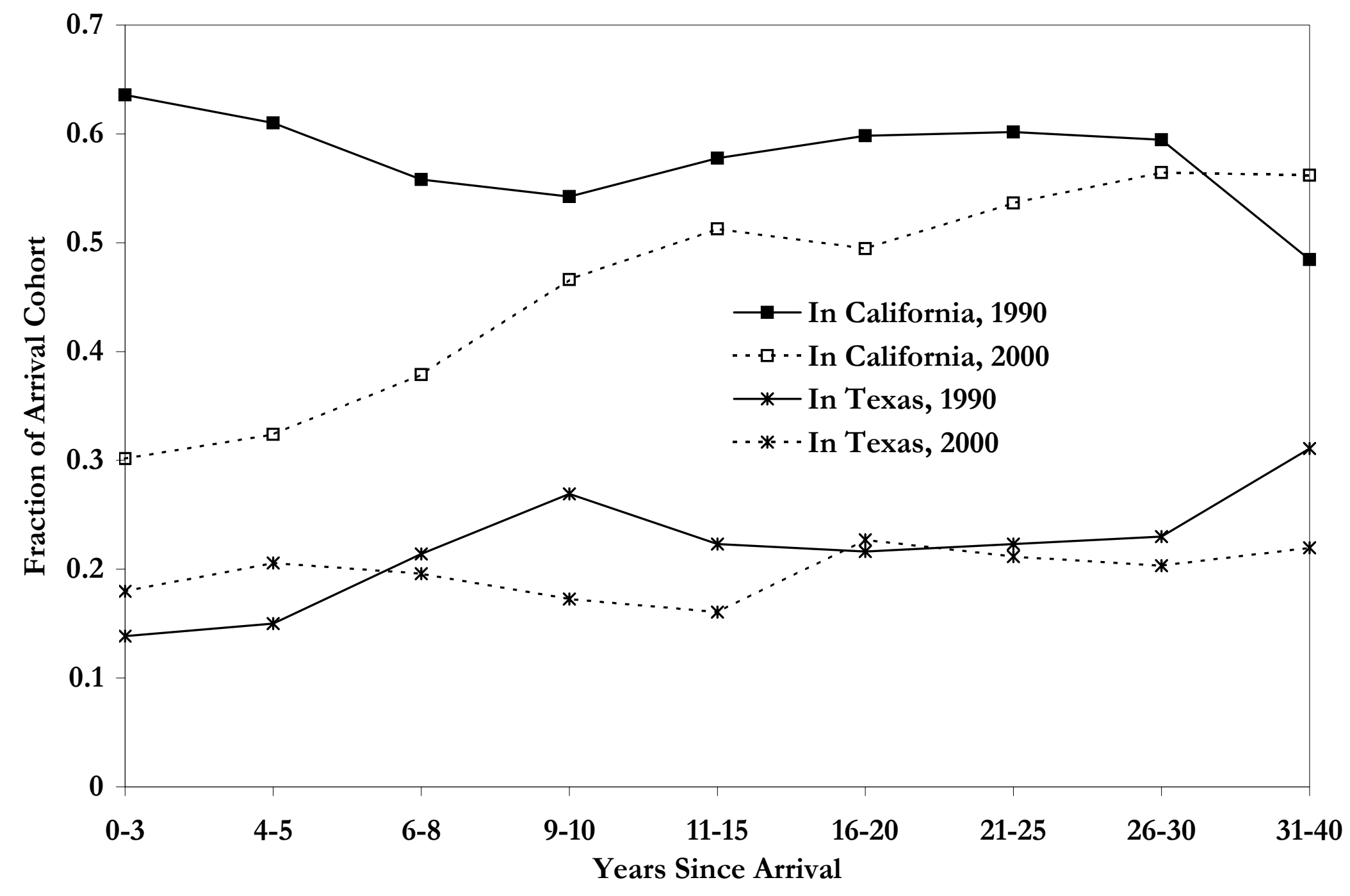


Figure 4: Fraction of Mexican Immigrants with Less than High School Education by Years Since Arrival

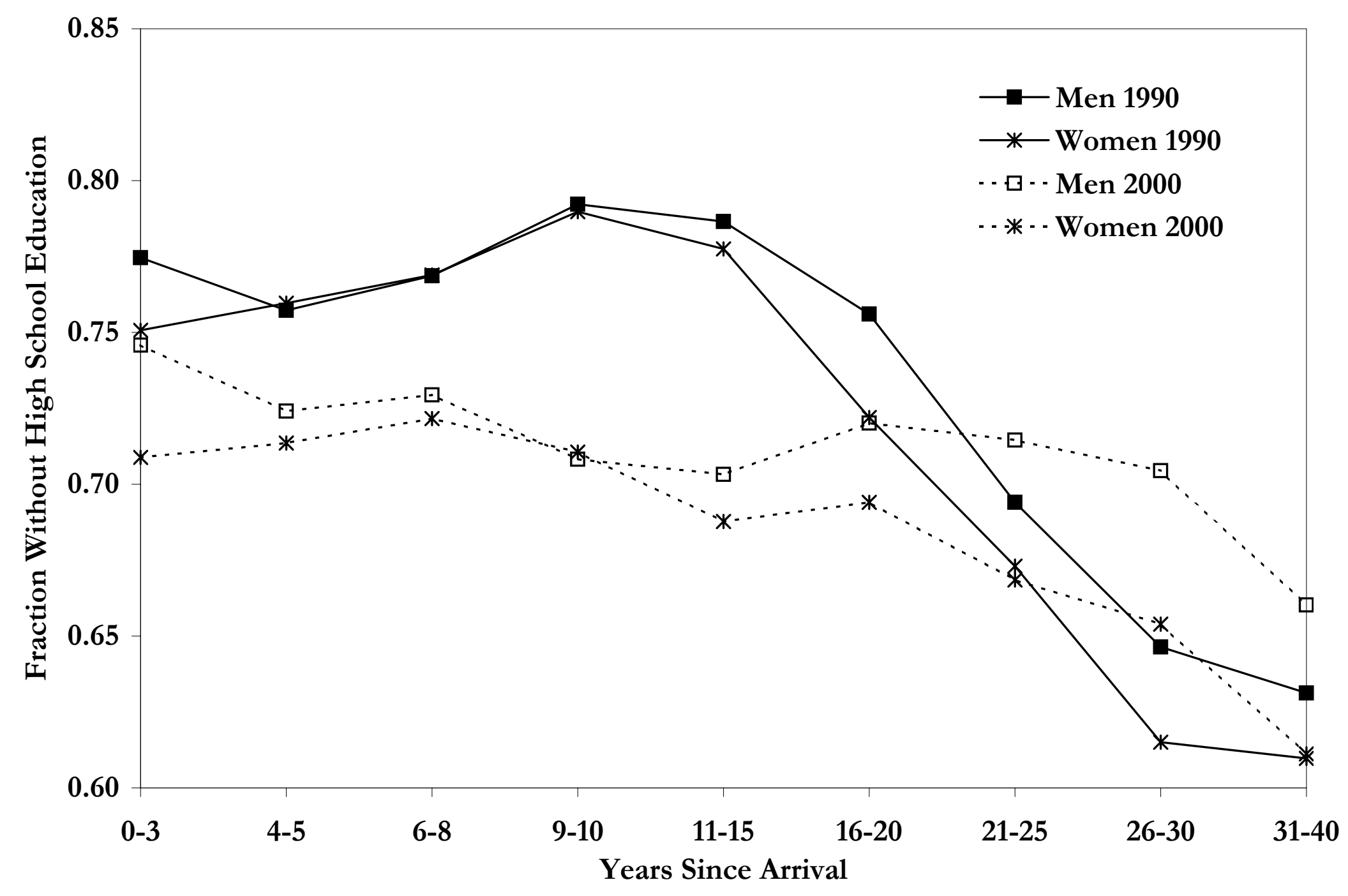


Figure 5: Fraction of Mexican Immigrants with Low English by Years Since Arrival

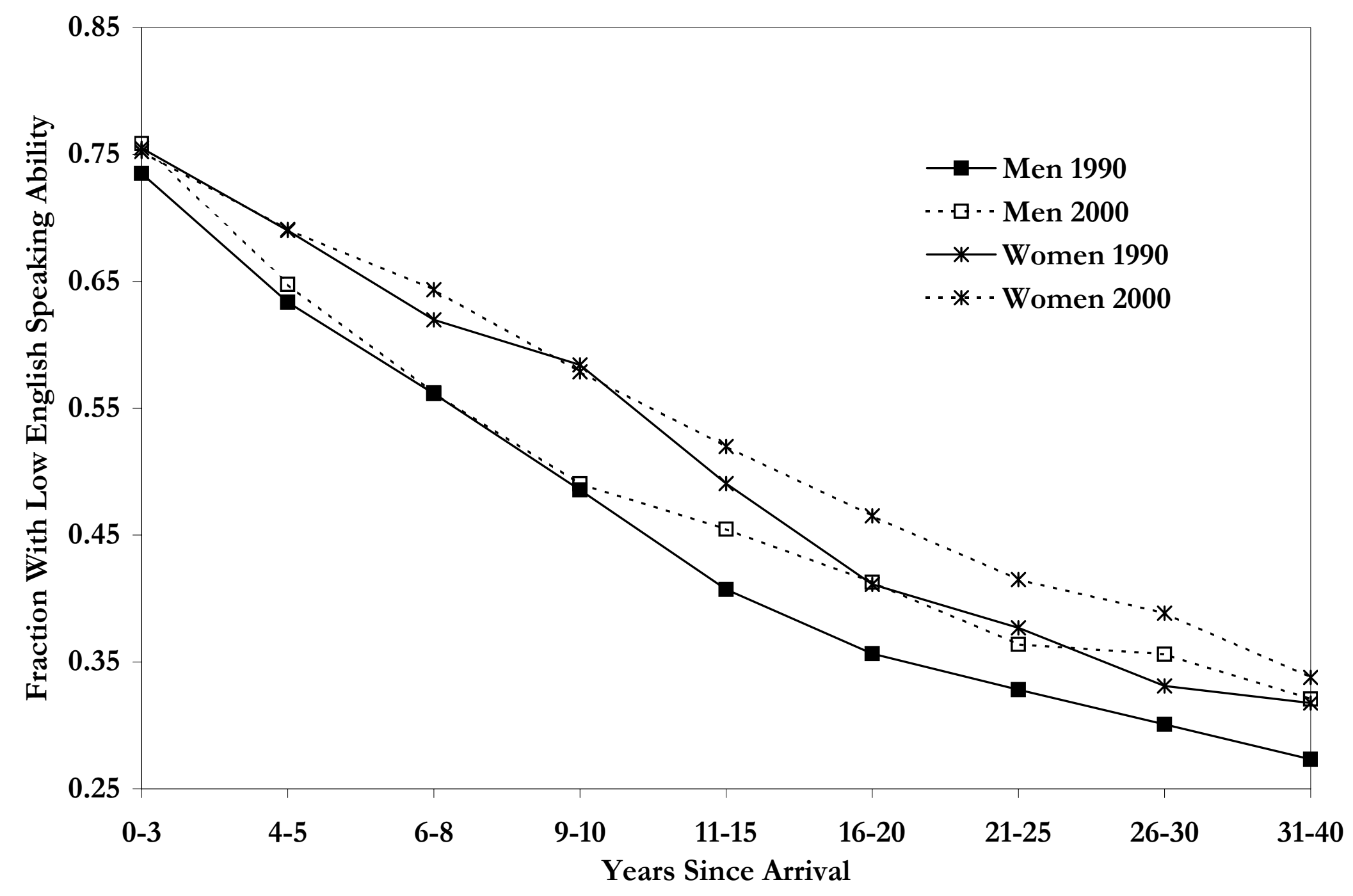


Figure 6: Mean Log Hourly Wages of Mexican Immigrants by Years Since Arrival

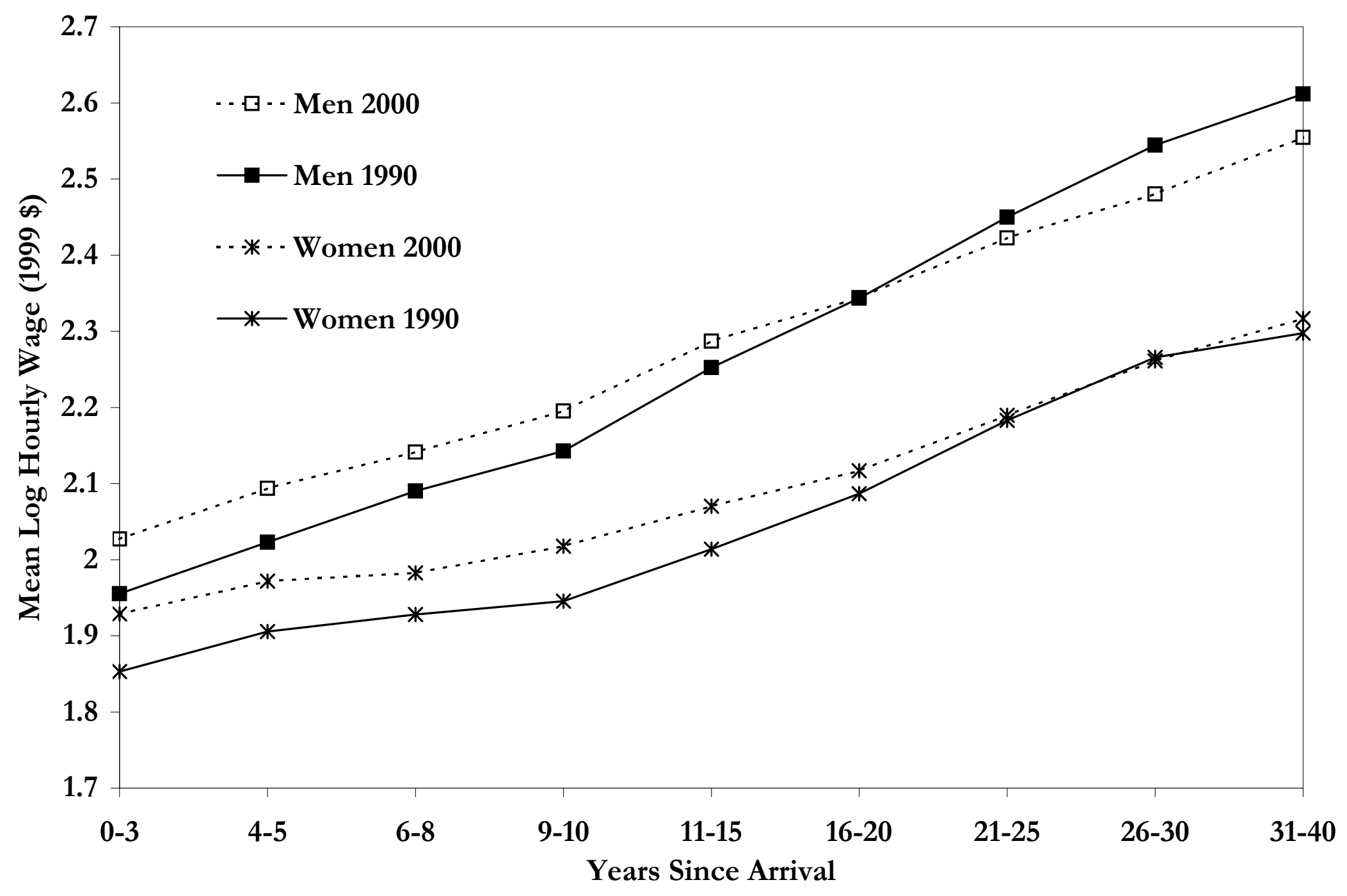


Figure 7: Fraction of Mexican Immigrants in Agriculture, by Years Since Arrival

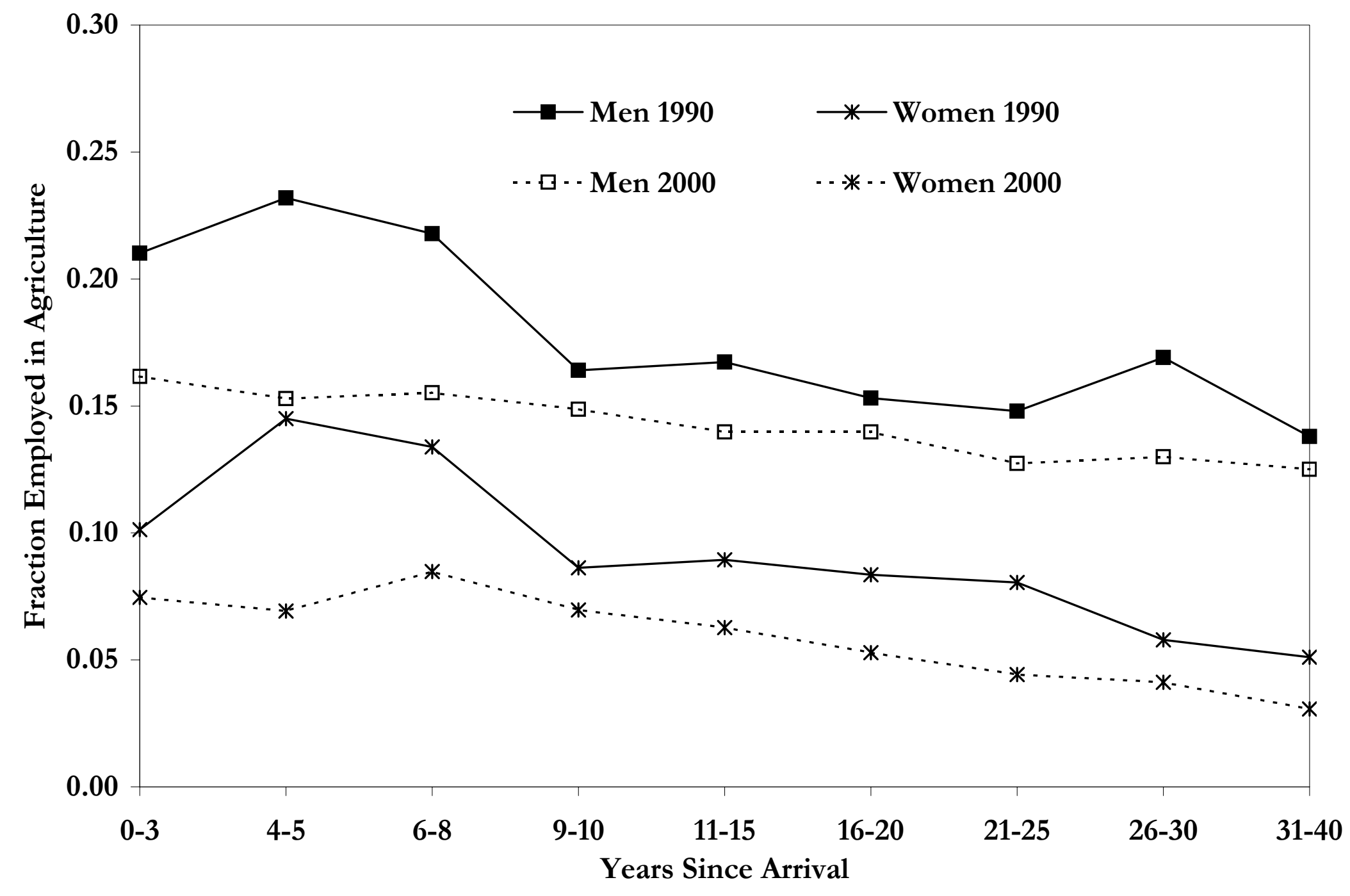


Figure 8: Fraction of Mexican Immigrants in Construction, by Years Since Arrival

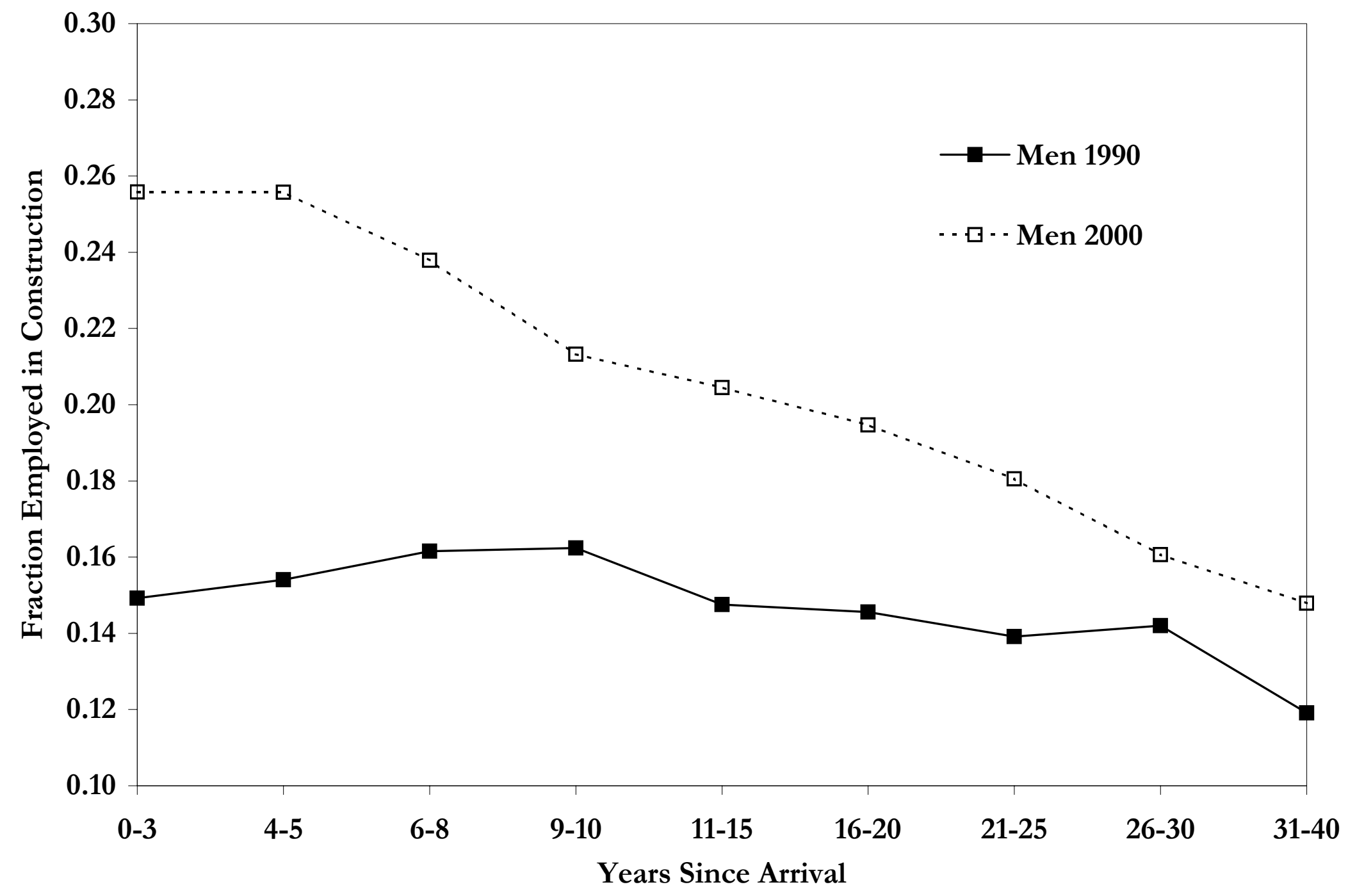


Figure 9: Fraction of Mexican Immigrants in Retail Trade, by Years Since Arrival

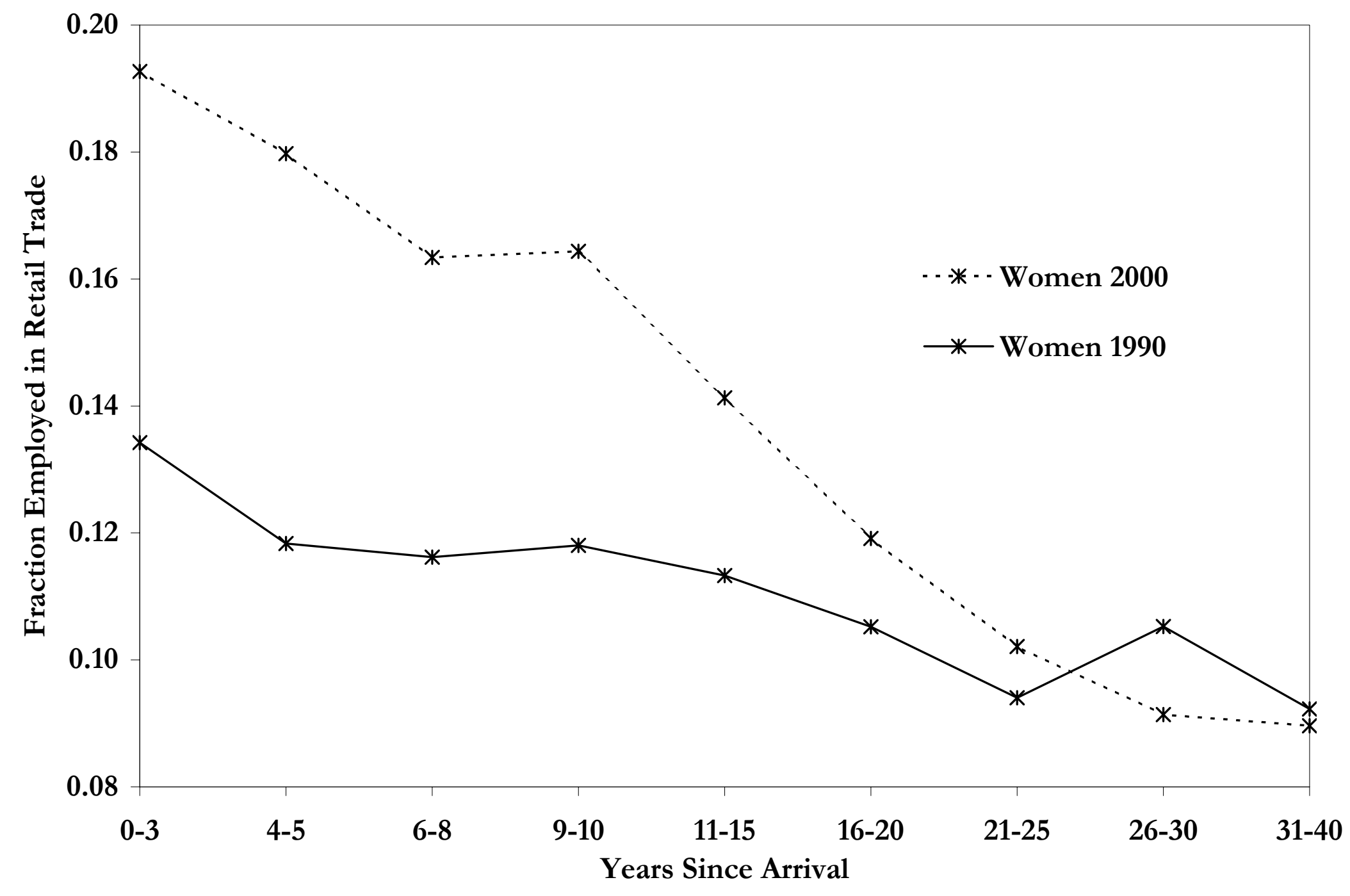


Figure 10: Inflow Rate of Mexican Immigrants and Change in Fraction of Dropouts

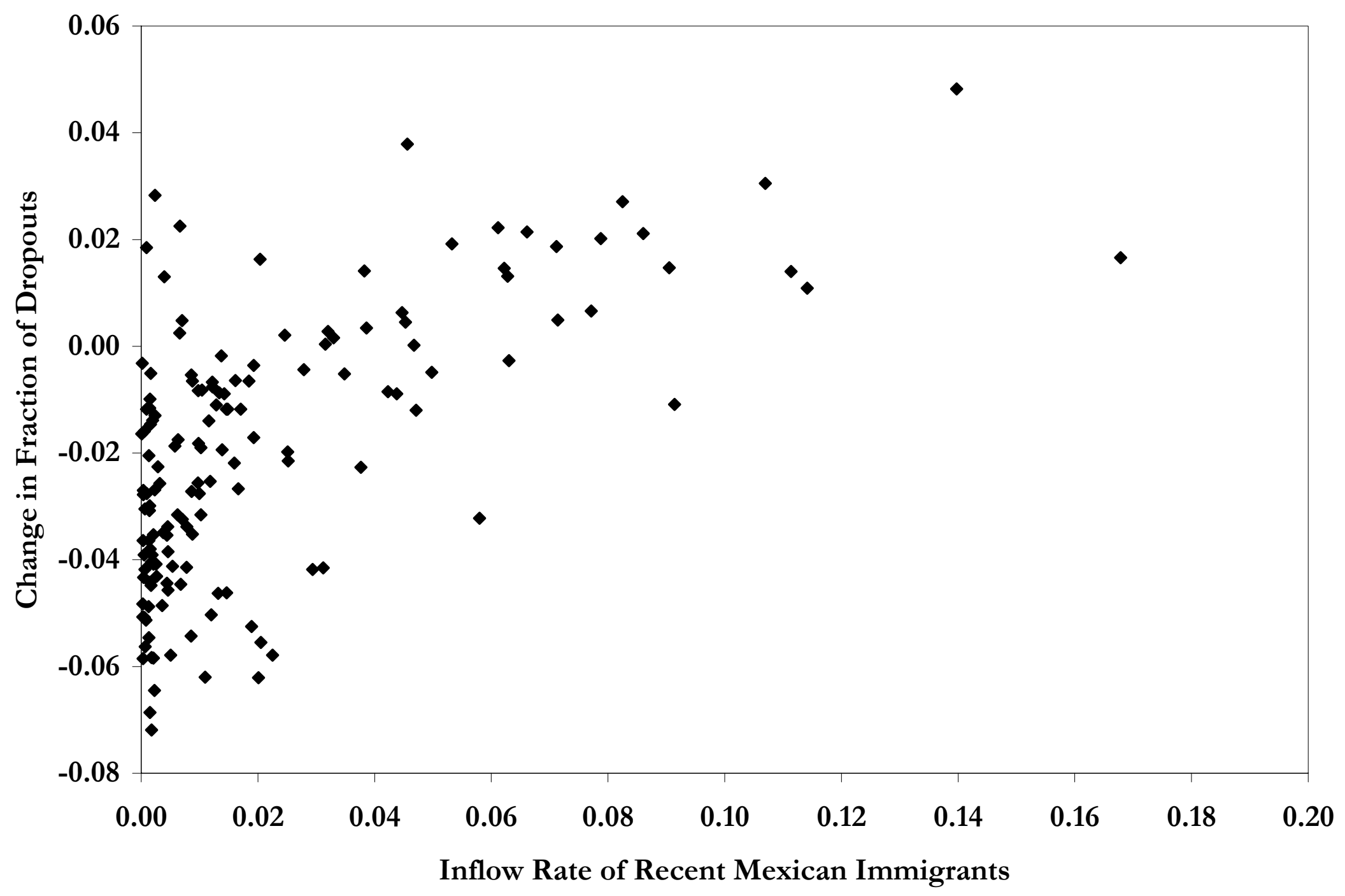


Figure 11: Contribution of Within-Industry Component to Absorption of Dropouts

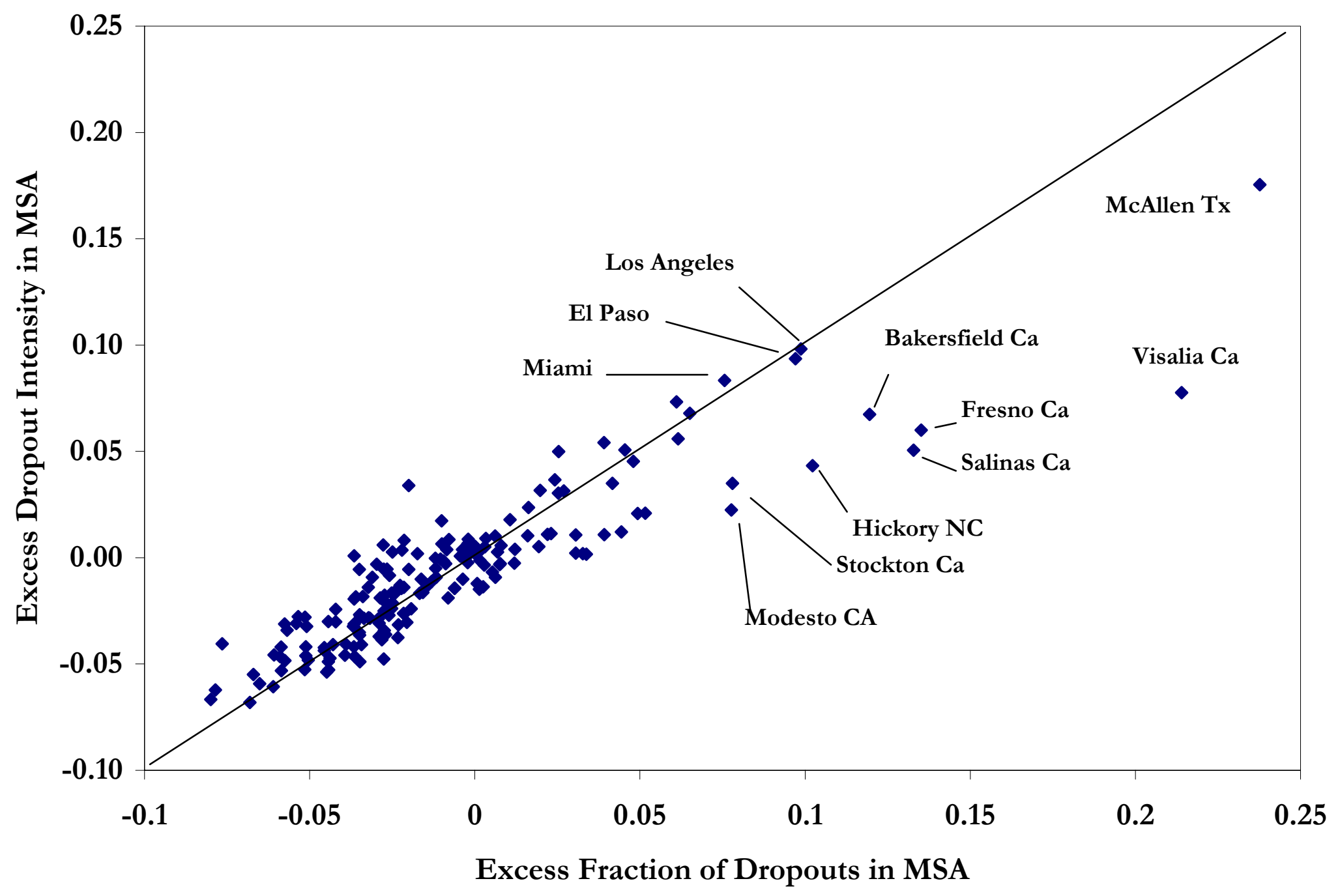


Figure 12: Contribution of Between-Industry Component to Absorption of Dropouts

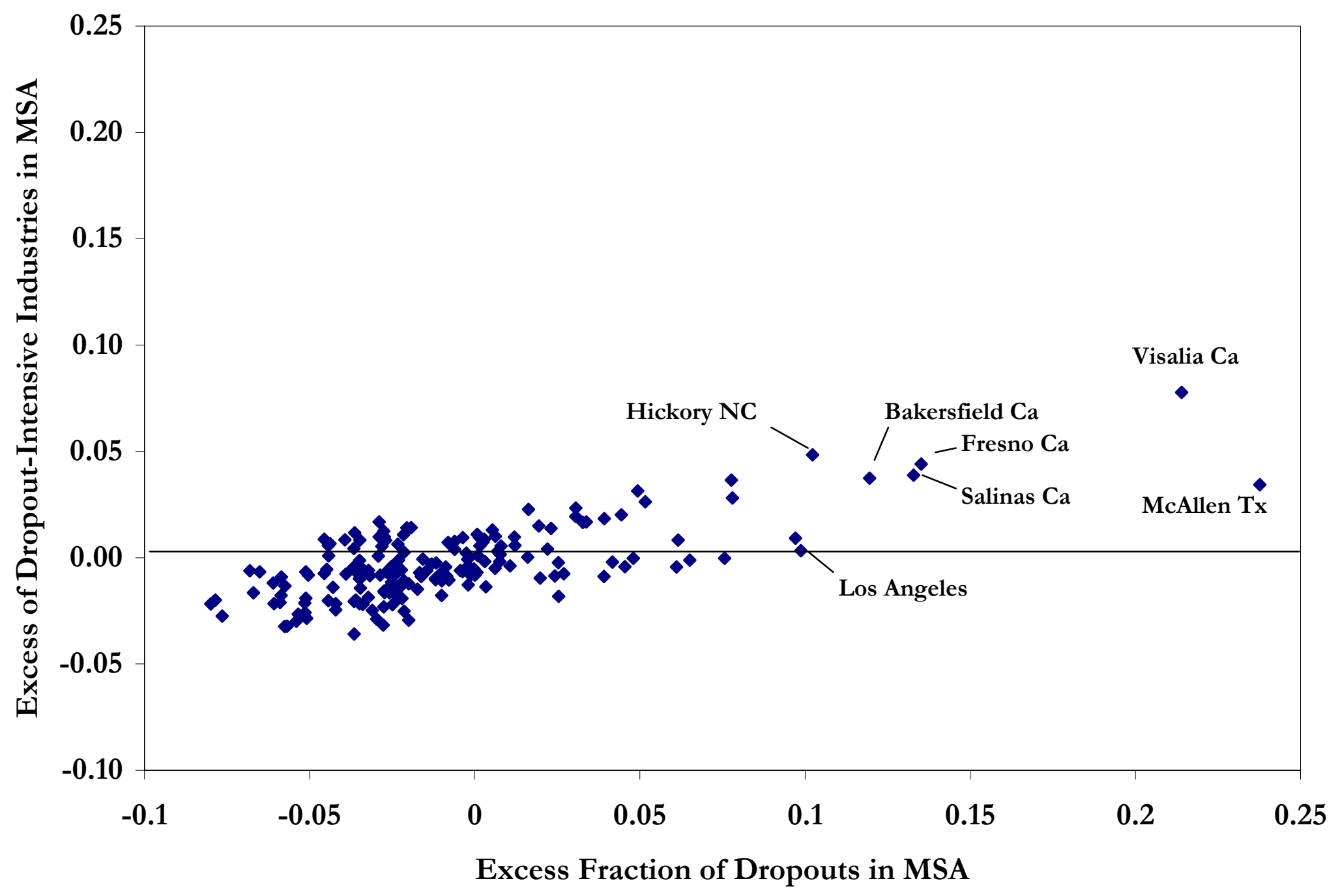


Figure 13: Contribution of Between-Industry Component to Absorption of Dropouts Excluding Agriculture

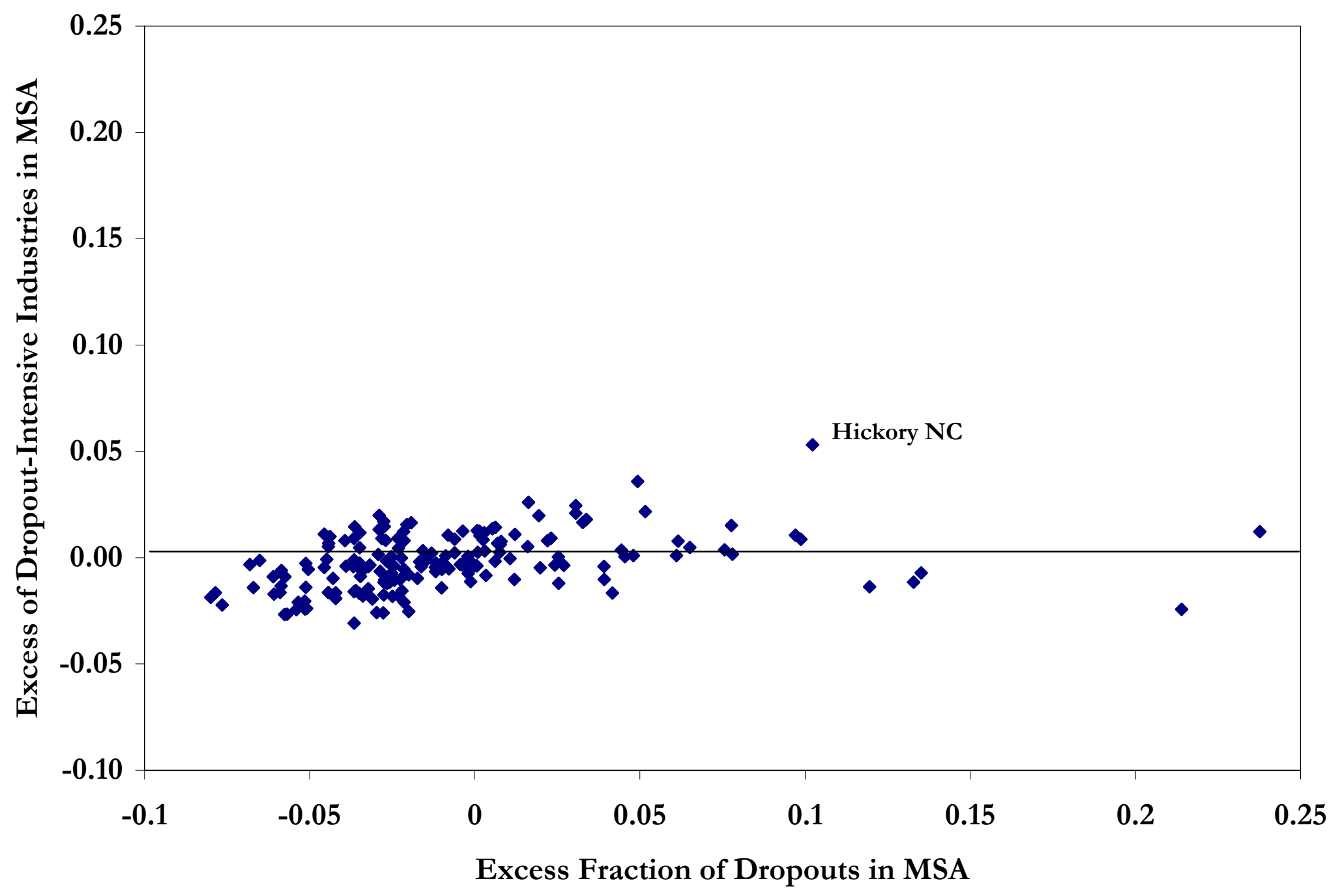


Figure 14: Contribution of Between-Industry Component to Absorption of Dropouts

Agriculture and Textiles/Apparel Industries

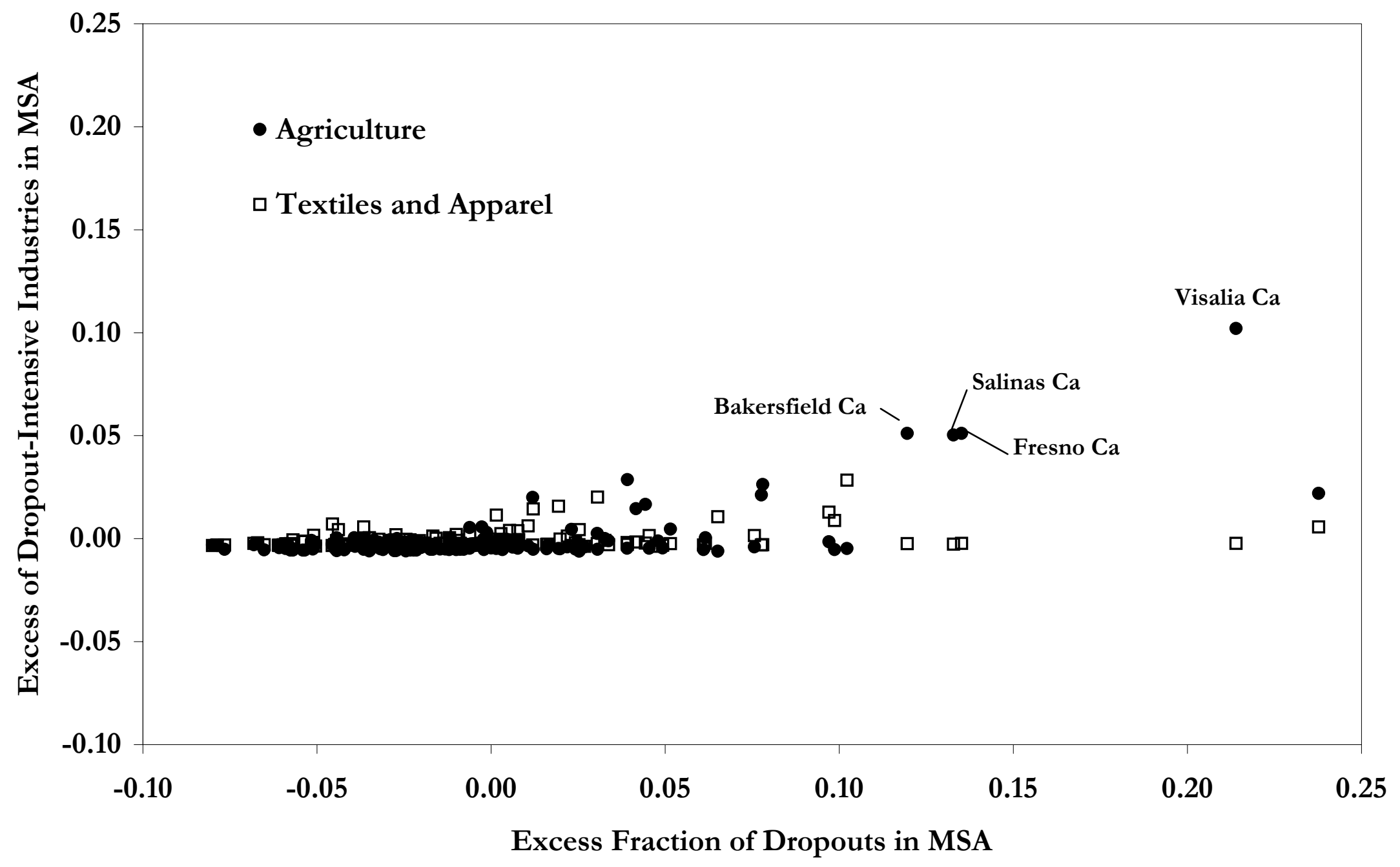


Figure 15: Within Industry Component of Absorption of Mexican Immigrant Workers

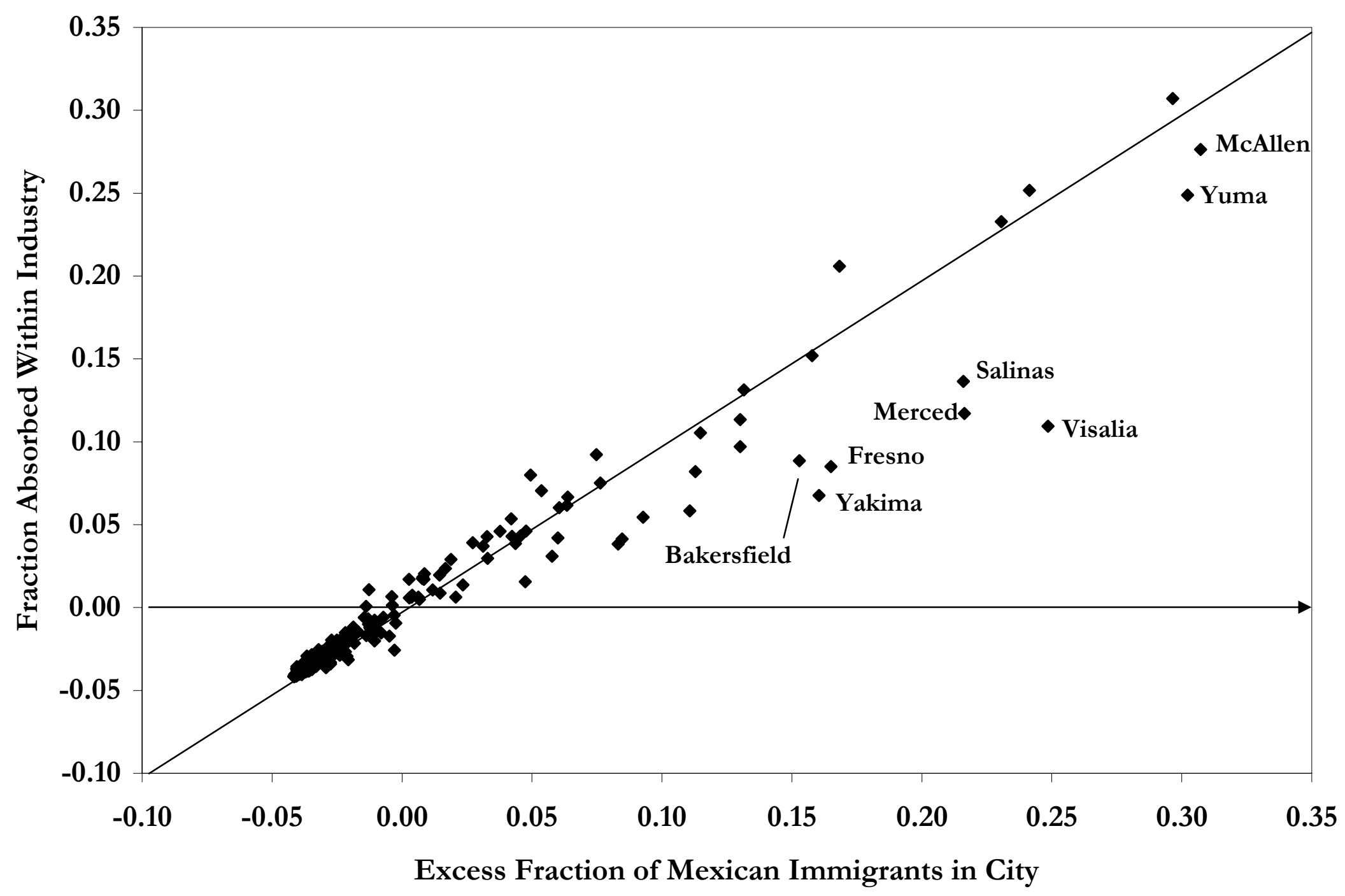


Figure 16: Inflow Rate of Mexican Immigrants and Change in Relative Supply of Dropout

\section{Labor}

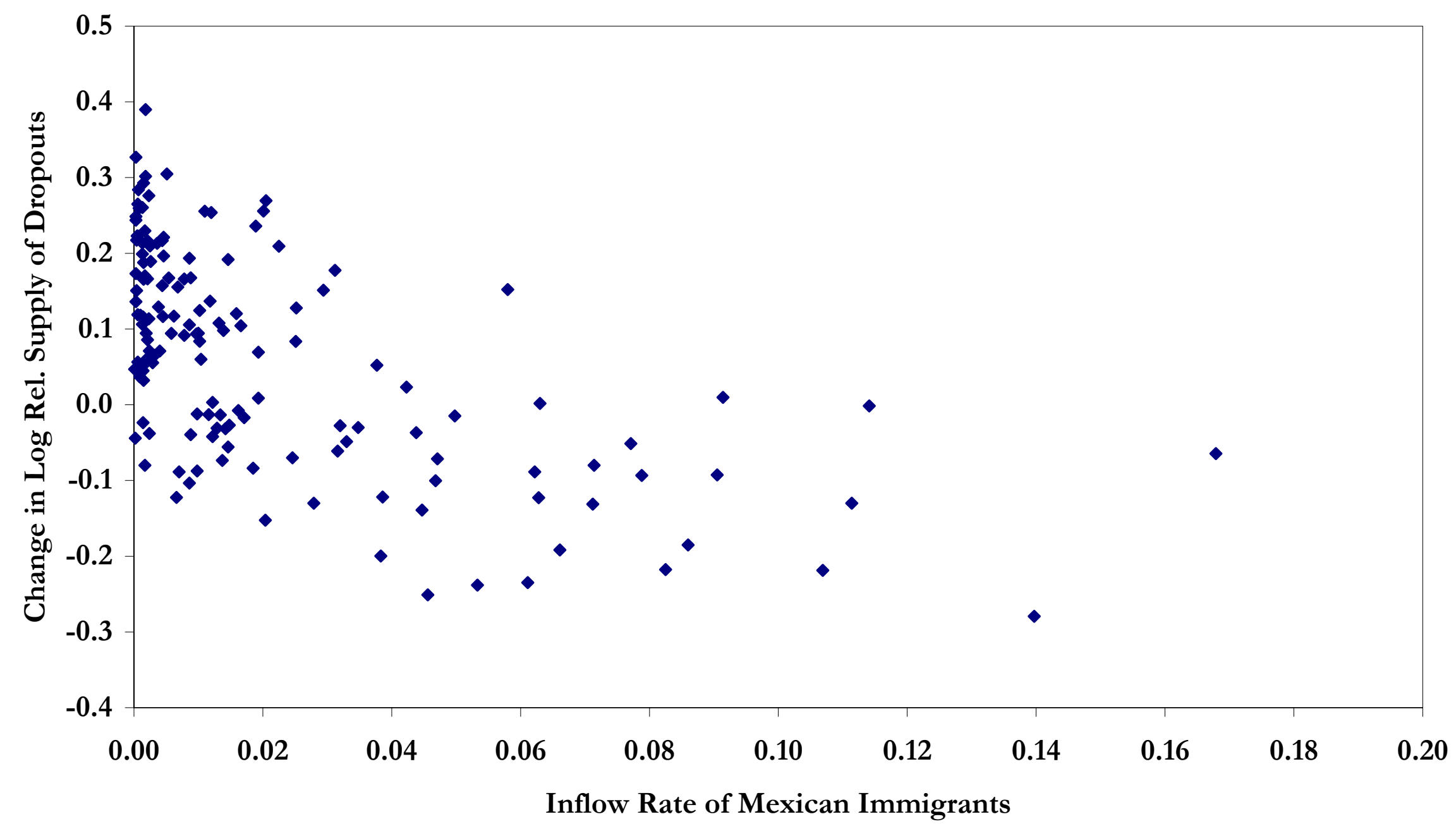


Figure 17: Inflow Rate of Mexican Immigrants and Change in Relative Wage of Native Male Dropouts

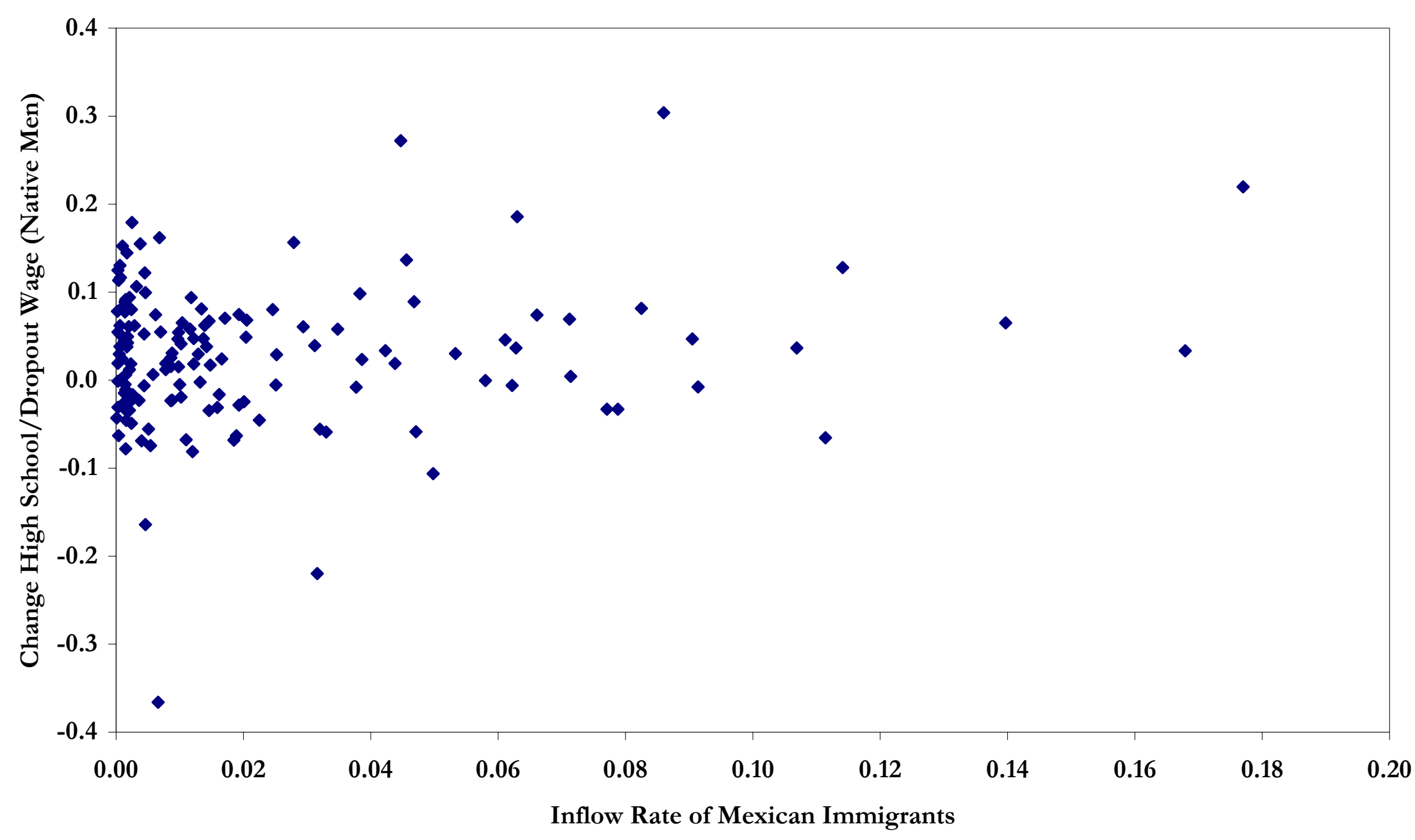

